\title{
Recent Advances in the Analysis of Steroid Hormones and Related Drugs
}

\author{
Sándor GöRöG
}

Gedeon Richter Ltd., P.O.B. 27, H-1475 Budapest, Hungary

\begin{abstract}
The development during the last 15 years and the state-of-the-art in the analysis of bulk steroid hormone drugs and hormone-like structures and pharmaceutical formulations made thereof are summarized. Other steroids (sterols, bile acids, cardiac glycosides, vitamins D) as well as biological-clinical aspects and pharmacokinetic and metabolic studies are excluded from this review. The state-of-the-art is summarized based on comparisons of monographs in the latest editions of the European Pharmacopoeia, United States Pharmacopoeia and the Japanese Pharmacopoeia. This is followed by sections dealing with new developments in the methodology for the fields of spectroscopic and spectrophotometric, chromatographic, electrophoretic and hyphenated techniques as well electroanalytical methods. The review is terminated by two problem-oriented sections: examples on impurity and degradation profiling as well as enantiomeric analysis.
\end{abstract}

(Received January 14, 2004; Accepted February 2, 2004)

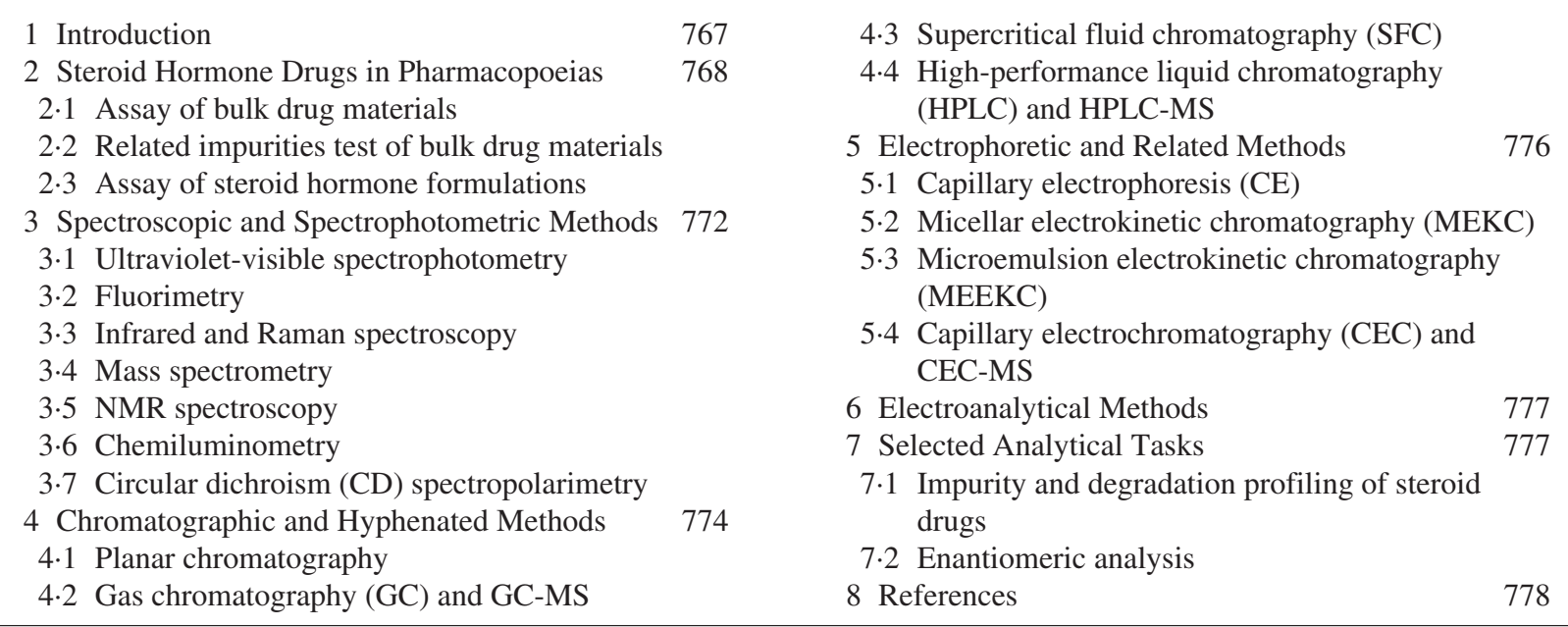

\section{Introduction}

The aim of this paper is to give an overview of the advances during the last 15 years and of the state-of-the-art in the analysis of steroid hormone drugs and related materials. Why just 15 years? My first book on steroid hormone drug analysis was published in $1978^{2}$ when this area was in transition state due to the introduction and rapid spreading of new techniques, mainly high-performance liquid chromatography (HPLC) and immunoassay methods. This was followed by another book in $1983^{3}$ dealing with wider areas (in addition to the analysis of hormone drugs other types of steroids and biological-clinical aspects). The third book, published in $1989^{4}$ (just 15 years ago), dealt mainly with pharmaceutical and industrial aspects. The

This paper is Part 56 in a series on "Analysis of Steroids"; for Part 55 see Ref. 1.

E-mail: s.gorog@richter.hu development in steroid hormone drug analysis during the last 15 years can be characterized by the facts that HPLC undoubtedly became the most important routinely used method and that the importance of hyphenated chromatographic-spectroscopic techniques is increasing. New techniques, mainly capillary electrophoresis (CE) and related techniques, such as micellar (or microemulsion) electrokinetic chromatography (MEKC, MEEKC), capillary electrochromatography (CEC), also attract wide interest in steroid analysis. Summarization of the results achieved with these methods will be the subject of this review.

Only hormone drugs, their semi-synthetic analogues and hormone-like structures are considered. Other groups of steroids (sterols, bile acids, cardiac glycosides, vitamins D, etc.) are not within the scope of this review. Pharmaceuticalindustrial aspects are discussed, such as assay and impurity profiling of bulk drugs and drug formulations, estimating degradation profiles. Biological-clinical aspects, pharmacokinetic and metabolic studies are also not within the scope of this review. These aspects are dealt with in a book of 
Makin et al. ${ }^{5}$ Spectroscopic studies are not discussed either unless these are part of impurity profiling and degradation profiling studies.

\section{Steroid Hormone Drugs in Pharmacopoeias}

Pharmacopoeias are naturally rather conservative: new techniques appear in their monographs only if proved by many years of practice that the performance of these methods is superior to that of the currently used methods. In spite of this limitation, the state-of-the-art of methodology and requirements in official drug analysis is well reflected by monographs concerning the latest revisions of the principal pharmacopoeias.

\subsection{Assay of bulk drug materials}

Table 1 shows a brief summarization of the assay and related impurities tests in the monographs of bulk steroid hormones and hormone-like structures in European Pharmacopoeia 4th ed. (Ph. Eur. IV), ${ }^{6}$ United States Pharmacopoeia 26th ed. (USP $\mathrm{XXVI})^{7}$ and the 14 th edition of the Japanese Pharmacopoeia (Ph. Jp. XIV). ${ }^{8}$

As can be seen in Table 1 , the most frequently used assay method in Ph. Eur. IV. is UV spectrophotometry at about 240 $\mathrm{nm}$ for steroids with strongly absorbing 4-ene-3-oxo-or 1,4diene-3-oxo group and at about 280 for estrogens with a phenoltype ring A with its weak, but characteristic, spectra. This method is naturally non-specific: the overwhelming majority of the impurities are measured together with the main component. The predominant method in the United States Pharmacopoeia is highly specific reversed phase (in some cases normal phase) HPLC. In the overwhelming majority of cases, porous octadecylsilica support $(3-10 \mu \mathrm{m})$ is used for the RP and porous silica support $(5-10 \mu \mathrm{m})$ for the NP separations. The wavelength of the UV detector is set most often at $254 \mathrm{~nm}$, which is not the maximum of the spectrum of 4-ene-3-oxo- or 1,4-diene-3-oxosteroids. This is attributable to the early period in the history of HPLC when the majority of instruments were equipped with only a mercury lamp. In the Japanese Pharmacopoeia the HPLC and UV spectrophotometric assay methods are almost equally represented. It is to be noted that UV spectrophotometry around $240 \mathrm{~nm}$ with limits for the specific absorbance is often part of the monographs as an identification test, even in those cases when the assay is carried out by HPLC methods.

It is interesting to note, and difficult to explain that in some instances visible spectrophotometric methods, such as a measurement around $380 \mathrm{~nm}$ after condensation of the unsaturated 3-oxo group with isoniazide, or an indirect measurement at $525 \mathrm{~nm}$ after a reaction with Tetrazolium Blue of corticosteroids with reducing side chain, is prescribed by the European and United States Pharmacopoeias; moreover, in one instance (mestranol) ${ }^{7}$ the assay is based on a non-stoichiometric color reaction with a methanol-sulfuric acid reagent $(545 \mathrm{~nm})$. The selectivity of these, rather outdated methods ${ }^{2-4,9,10}$ is not better than that of the spectrophotometric methods based on native absorbance measurements.

Although the overwhelming majority of steroid hormone drugs do not posses functional groups suitable for titration, in some cases this method is still used. Ethinylsteroids can be titrated with sodium hydroxide after a reaction with silver nitrate and the liberation of nitric acid. This method is used as a (non specific) assay method by $\mathrm{Ph}$. Eur. and $\mathrm{Ph}$. Jp. and as a "Limit of ethynyl group" by the United States Pharmacopoeia. Other titrimetric methods are restricted to the titration of pancuronium bromide $^{6,8}$ and stanozolol $^{6,7}$ with acetous perchloric acid. The lactone group in oxandrolone, ${ }^{7}$ after opening it with sodium hydroxide and the $-\mathrm{O}-\mathrm{SO}_{2}-\mathrm{ONa}$ group in sodium prasterone sulfate ${ }^{8}$ after $\mathrm{Na}^{+} \rightarrow \mathrm{H}^{+}$ion exchange, are also suitable for titrimetric determination.

Of the chromatographic methods other than HPLC, gas chromatography is only very seldom used for the assay of bulk steroid hormone drugs. The outdated and labor-consuming method of TLC separation and UV spectrophotometry after spot elution is prescribed for the assay of meprednisone, nandrolone phenylpropionate, prednisolone hemisuccinate and testosterone. $^{7}$

\subsection{Related impurities test of bulk drug materials}

The test for "Related substances", 6 also named "Chromatographic purity",7 "Ordinary impurities", "Related steroids" or "Other steroids", ${ }^{8}$ is the most important test to characterize the quality of a bulk drug material, much more important than the assay, especially if the latter is carried out by non-specific methods.

As can be seen in Table 1, with two exceptions (conjugated and esterified estrogens, where gas chromatography is used), this test is carried out in all cases by semi-quantitative TLC or quantitative (mainly but not exclusively reversed phase) HPLC methods. The proportion of HPLC tests for related impurities in bulk steroids in various pharmacopoeias is quite different: about $75 \%$ in $\mathrm{Ph}$. Eur. IV, $50 \%$ in USP XXVI and $10 \%$ in $\mathrm{Ph} . \mathrm{Jp}$. XIV. It is amazing that in many cases the USP XXVI and $\mathrm{Ph}$. Jp. XIV do not contain tests for related impurities (27 and 10\%, respectively).

In the case of HPLC tests, a UV detector is exclusively used at the wavelength of the maximum of the main component or at $254 \mathrm{~nm}$. For the thin-layer chromatographic purity test in the majority of cases, sorbent layers are used that are impregnated with dyes strongly fluorescing when irradiated at $254 \mathrm{~nm}$ by a mercury lamp. Since most of the steroid hormone drugs strongly absorb UV light at this wavelength, the drugs and their impurities appear as dark spots in the chromatogram suitable for their semi-quantitative estimation. These appear as "TLC 254 $\mathrm{nm}$ " in Table 1. In some cases the use of various visualizing reagents is necessary. Reagents containing sulfuric acid are most frequently used. "TLC- $\mathrm{H}_{2} \mathrm{SO}_{4}$ " in Table 1 means spraying with this reagent, heating and visual inspection of the plate and the use of long-wavelength UV light (366 nm). Other visualizing reagents are phosphomolybdic acid (TLC-phosph.mol.), p-toluenesulfonic acid, vanillin/sulfuric acid (TLC-vanillin), potassium dichromate/sulfuric acid (TLC-acid dichromate), iodine vapor (TLC- $\mathrm{I}_{2}$ ) and alkaline Blue Tetrazolium (TLC-tetrazolium). With a few exceptions, both the TLC and HPLC tests express the impurities as the main component, which can be source of serious errors (under- or overestimation) if the chromophoric system or the color and/or the intensity of the TLC spot of the main component and the impurity are different.

The use of other methods, such as the extraction of free corticosteroids from the solution of their water soluble esters, or elution of TLC spots followed by UV spectrophotometric measurement or gas chromatography, is restricted to a few cases.

\subsection{Assay of steroid hormone formulations}

In this section the state-of-the-art in the field of determining the active ingredient content of steroid hormone formulations is based mainly on USP XXVI, since the European Pharmacopoeia does not contain monographs for formulations 
Table 1 Assay and related impurities tests in European, USP and Japanese pharmacopoeias

\begin{tabular}{|c|c|c|c|c|c|c|}
\hline & \multicolumn{3}{|c|}{ Assay } & \multicolumn{3}{|c|}{ Related impurity } \\
\hline & Ph. Eur. 4 & USP XXVI & Ph.Jp. XIV & Ph. Eur. 4 & USP XXVI & Ph. Jp XIV \\
\hline $\begin{array}{l}\text { Alclometasone } \\
\text { dipropionate }\end{array}$ & - & RP-HPLC $254 \mathrm{~nm}$ & - & - & TLC $254 \mathrm{~nm}$ & - \\
\hline Amcinonide & - & RP-HPLC $254 \mathrm{~nm}$ & - & - & - & - \\
\hline $\begin{array}{l}\text { Beclomethasone } \\
\text { dipropionate }\end{array}$ & VIS-tetrazolium & RP-HPLC $254 \mathrm{~nm}$ & RP-HPLC $254 \mathrm{~nm}^{-}$ & -RP-HPLC 254 nm & - & TLC-tetrazolium \\
\hline Betamethasone & UV $238.5 \mathrm{~nm}$ & RP-HPLC $240 \mathrm{~nm}$ & RP-HPLC 240 nm & TLC- $\mathrm{H}_{2} \mathrm{SO}_{4}$ & TLC- $\mathrm{H}_{2} \mathrm{SO}_{4}$ & TLC $254 \mathrm{~nm}$ \\
\hline -acetate & UV $240 \mathrm{~nm}$ & RP-HPLC $254 \mathrm{~nm}$ & - & RP-HPLC 254 nm & TLC $254 \mathrm{~nm}$ & - \\
\hline -benzoate & - & RP-HPLC $254 \mathrm{~nm}$ & - & - & TLC $254 \mathrm{~nm}$ & - \\
\hline -dipropionate & UV $240 \mathrm{~nm}$ & RP-HPLC $254 \mathrm{~nm}$ & UV $239 \mathrm{~nm}$ & RP-HPLC 254 nm & RP-HPLC $254 \mathrm{~nm}$ & TLC $254 \mathrm{~nm}$ \\
\hline $\begin{array}{l}\text {-sodium } \\
\text { phosphate }\end{array}$ & UV $241 \mathrm{~nm}$ & RP-HPLC 254 nm & RP-HPLC 254 nm & RP-HPLC 254 nm & $\begin{array}{l}\text { Betamethasone- } \\
\text { extraction } 239 \mathrm{~nm}\end{array}$ & TLC $254 \mathrm{~nm}$ \\
\hline -valerate & UV 240 nm & RP-HPLC $254 \mathrm{~nm}$ & RP-HPLC 254 nm & RP-HPLC 254 nm & RP-HPLC $254 \mathrm{~nm}$ & TLC-tetrazolium \\
\hline Budesonide & RP-HPLC 240nm & - & - & RP-HPLC 240 nm & - & - \\
\hline $\begin{array}{l}\text { Chlormadinone } \\
\text { acetete }\end{array}$ & - & - & UV $285 \mathrm{~nm}$ & - & - & RP-HPLC 236nm \\
\hline $\begin{array}{l}\text { Clobetasol } \\
\text { propionate }\end{array}$ & - & RP-HPLC $240 \mathrm{~nm}$ & - & - & RP-HPLC $240 \mathrm{~nm}$ & - \\
\hline $\begin{array}{l}\text { Clobetasone } \\
\text { butyrate }\end{array}$ & UV $235 \mathrm{~nm}$ & - & - & RP-HPLC $241 \mathrm{~nm}$ & - & - \\
\hline $\begin{array}{l}\text { Clocortolone } \\
\text { pivalate }\end{array}$ & - & VIS-isoniazid & - & - & TLC/elut $238 \mathrm{~nm}$ & - \\
\hline Cortisone acetate & UV $237 \mathrm{~nm}$ & RP-HPLC $254 \mathrm{~nm}$ & - & RP-HPLC 254 nm & RP-HPLC $254 \mathrm{~nm}$ & - \\
\hline $\begin{array}{l}\text { Cyproterone } \\
\text { acetate }\end{array}$ & UV $282 \mathrm{~nm}$ & - & - & RP-HPLC 254 nm & - & - \\
\hline Danazol & - & UV $285 \mathrm{~nm}$ & - & - & TLC- $\mathrm{I}_{2}$ & - \\
\hline $\begin{array}{l}\text { Desoxycort(icoster) } \\
\text { one acetate }\end{array}$ & UV $240 \mathrm{~nm}$ & VIS-tetrazolium & - & RP-HPLC 254 nm & - & - \\
\hline -pivalate & - & RP-HPLC $254 \mathrm{~nm}$ & - & - & - & - \\
\hline Desoximetasone & - & RP-HPLC 254 nm & - & - & - & - \\
\hline Dexamethasone & UV $238.5 \mathrm{~nm}$ & RP-HPLC $254 \mathrm{~nm}$ & RP-HPLC 254 nm & RP-HPLC 254 nm & RP-HPLC $254 \mathrm{~nm}$ & TLC $254 \mathrm{~nm}$ \\
\hline -acetate & UV $238.5 \mathrm{~nm}$ & RP-HPLC $254 \mathrm{~nm}$ & - & RP-HPLC 254 nm & RP-HPLC $254 \mathrm{~nm}$ & - \\
\hline $\begin{array}{l}\text {-sodium } \\
\text { phosphate }\end{array}$ & UV $241.5 \mathrm{~nm}$ & RP-HPLC 254 nm & - & RP-HPLC 254 nm & RP-HPLC 254 nm & - \\
\hline $\begin{array}{l}\text { Diflorasone } \\
\text { diacetate }\end{array}$ & - & NP-HPLC 254 nm & - & - & NP-HPLC 254 nm & - \\
\hline $\begin{array}{l}\text { Drostanolone } \\
\text { propionate }\end{array}$ & - & - & GC & - & - & TLC-vanillin \\
\hline Dydrogesterone & - & RP-HPLC $280 \mathrm{~nm}$ & - & - & RP-HPLC $280 \mathrm{~nm}$ & - \\
\hline Estradiol & UV $238 \mathrm{~nm} \mathrm{NaOH}$ & RP-HPLC $205 \mathrm{~nm}$ & - & RP-HPLC 280 nm & NP-HPLC $280 \mathrm{~nm}$ & - \\
\hline -benzoate & UV $231 \mathrm{~nm}$ & - & RP-HPLC 230 nm & RP-HPLC 230 nm & - & TLC $254 \mathrm{~nm}$ \\
\hline -cypionate & - & RP-HPLC $280 \mathrm{~nm}$ & - & - & - & - \\
\hline -valerate & UV $280 \mathrm{~nm}$ & RP-HPLC $280 \mathrm{~nm}$ & - & RP-HPLC 220 nm & TLC- $\mathrm{H}_{2} \mathrm{SO}_{4}$ & - \\
\hline Estriol & UV $281 \mathrm{~nm}$ & UV $281 \mathrm{~nm}$ & RP-HPLC $280 \mathrm{~nm}$ & NP-HPLC 254 nm & TLC- $\mathrm{H}_{2} \mathrm{SO}_{4}$ & TLC- $\mathrm{H}_{2} \mathrm{SO}_{4}$ \\
\hline $\begin{array}{l}\text { Estrogens, } \\
\text { conjugated }\end{array}$ & GC & $\mathrm{GC}$ & - & GC & $\mathrm{GC}$ & - \\
\hline $\begin{array}{l}\text { Estrogens, } \\
\text { esterified }\end{array}$ & - & GC & - & - & GC & - \\
\hline Estrone & - & RP-HPLC $280 \mathrm{~nm}$ & - & - & $\mathrm{TLC}-\mathrm{H}_{2} \mathrm{SO}_{4}$ & - \\
\hline Estropipate & - & RP-HPLC $213 \mathrm{~nm}$ & - & - & RP-HPLC $213 \mathrm{~nm}$ & - \\
\hline Ethinylestradiol & Titration ethinyl & RP-HPLC $280 \mathrm{~nm}$ & Titration ethinyl & RP-HPLC 280 nm & - & Estrone-colorim. \\
\hline $\begin{array}{l}\text { Ethynodiol } \\
\text { diacetate }\end{array}$ & - & RP-HPLC $200 \mathrm{~nm}$ & - & - & RP-HPLC $200 \mathrm{~nm}$ & - \\
\hline Finasteride & RP-HPLC $210 \mathrm{~nm}$ & RP-HPLC $215 \mathrm{~nm}$ & - & RP-HPLC 210 nm & RP-HPLC $210 \mathrm{~nm}$ & - \\
\hline $\begin{array}{l}\text { Fludrocortisone } \\
\text { acetate }\end{array}$ & UV $238 \mathrm{~nm}$ & VIS-tetrazolium & - & RP-HPLC 254 nm & TLC $254 \mathrm{~nm}$ & - \\
\hline $\begin{array}{l}\text { Flumetasone } \\
\text { pivalate }\end{array}$ & UV $239 \mathrm{~nm}$ & VIS-tetrazolium & - & RP-HPLC 254 nm & TLC- $\mathrm{H}_{2} \mathrm{SO}_{4}$ & - \\
\hline Flunisolide & - & RP-HPLC $254 \mathrm{~nm}$ & - & - & TLC $254 \mathrm{~nm}$ & - \\
\hline $\begin{array}{l}\text { Fluocinolone } \\
\text { acetonide }\end{array}$ & UV $238 \mathrm{~nm}$ & RP-HPLC 254 nm & RP-HPLC 254 nm & RP-HPLC 238 nm & - & RP-HPLC $254 \mathrm{~nm}$ \\
\hline Fluocinonide & - & RP-HPLC $254 \mathrm{~nm}$ & RP-HPLC 254 nm & - & RP-HPLC 254 nm & TLC-tetrazolium \\
\hline $\begin{array}{l}\text { Fluocortolone } \\
\text { pivalate }\end{array}$ & UV $242 \mathrm{~nm}$ & - & - & RP-HPLC 243 nm & - & - \\
\hline Fluorometholone & - & RP-HPLC $254 \mathrm{~nm}$ & RP-HPLC 254 nm & - & - & TLC $254 \mathrm{~nm}$ \\
\hline
\end{tabular}




\begin{tabular}{|c|c|c|c|c|c|c|}
\hline Fluoxymesterone & - & RP-HPLC 254 nm & NP-HPLC 254 nm & - & RP-HPLC 254 nm & TLC 254 nm \\
\hline Flurandrenolide & - & RP-HPLC 240 nm & - & - & TLC $254,366 \mathrm{~nm}$ & - \\
\hline $\begin{array}{l}\text { Fluticasone } \\
\text { propionate }\end{array}$ & RP-HPLC 239 nm & - & - & RP-HPLC 239 nm & - & - \\
\hline Halcinonide & - & UV 239 nm & - & - & TLC/elut. $239 \mathrm{~nm}$ & - \\
\hline Hydrocortisone & UV $241.5 \mathrm{~nm}$ & NP-HPLC 254 nm & NP-HPLC 254 nm & RP-HPLC 254 nm & NP-HPLC 254 nm & TLC 254 nm \\
\hline -acetate & UV $241.5 \mathrm{~nm}$ & NP-HPLC 254 nm & RP-HPLC 254 nm & RP-HPLC 254 nm & RP-HPLC 254 nm & TLC-tetrazolium \\
\hline -butyrate & - & RP-HPLC 254 nm & UV $241 \mathrm{~nm}$ & - & RP-HPLC 254 nm & TLC-tetrazolium \\
\hline $\begin{array}{l}\text {-hydrogen } \\
\text { (hemi)succinate }\end{array}$ & UV $241.5 \mathrm{~nm}$ & NP-HPLC 254 nm & - & RP-HPLC 254 nm & RP-HPLC 254 nm & - \\
\hline $\begin{array}{l}\text {-sodium } \\
\text { phosphate }\end{array}$ & - & $\begin{array}{l}\text { Enzime, extraction } \\
239 \mathrm{~nm}\end{array}$ & RP-HPLC 254 nm & - & $\begin{array}{l}\text { Hydrocortisone, } \\
\text { extraction } 239 \mathrm{~nm}\end{array}$ & RP-HPLC 254nm \\
\hline $\begin{array}{l}\text {-sodium } \\
\text { succinate }\end{array}$ & - & VIS-tetrazolium & UV $240 \mathrm{~nm}$ & - & - & TLC $254 \mathrm{~nm}$ \\
\hline -for injection & - & NP-HPLC 254 nm & - & - & NP-HPLC 254 nm & - \\
\hline -succinate & - & - & RP-HPLC 254 nm & - & - & TLC $254 \mathrm{~nm}$ \\
\hline -valerate & - & RP-HPLC $254 \mathrm{~nm}$ & - & - & - & - \\
\hline $\begin{array}{l}\text { Hydroxyprogesteron } \\
\text { caproate }\end{array}$ & - & UV $240 \mathrm{~nm}$ & - & - & TLC- $\mathrm{H}_{2} \mathrm{SO}_{4}$ & - \\
\hline $\begin{array}{l}\text { Isoflupredone } \\
\text { acetate }\end{array}$ & - & NP-HPLC 254 nm & - & - & RP-HPLC 254 nm & - \\
\hline Levonorgestrel & Titration ethinyl & UV 241 nm & - & TLC-phos.mol. & TLC-phos.mol. & - \\
\hline Lynestrenol & Titration ethinyl & - & - & TLC- $\mathrm{H}_{2} \mathrm{SO}_{4}$ & - & - \\
\hline $\begin{array}{l}\text { Medroxyprogester- } \\
\text { one acetate }\end{array}$ & UV $241 \mathrm{~nm}$ & RP-HPLC 254 nm & - & RP-HPLC 254 nm & RP-HPLC 254 nm & - \\
\hline Megestrol acetate & UV $287 \mathrm{~nm}$ & RP-HPLC 280 nm & - & RP-HPLC 254 nm & - & - \\
\hline Mepitiostane & - & - & RP-HPLC 265 nm & - & - & TLC- $\mathrm{H}_{2} \mathrm{SO}_{4}$ \\
\hline Meprednisone & - & TLC $238 \mathrm{~nm}$ extr. & - & - & - & - \\
\hline Mesterolone & RP-HPLC 254 nm & - & - & $\begin{array}{l}\text { RP-HPLC } 200 \mathrm{~nm} \\
\text { TLC-p-toluene- } \\
\text { sulfonic acid }\end{array}$ & - & - \\
\hline Mestranol & Titration ethinyl & VIS- $\mathrm{H}_{2} \mathrm{SO}_{4}$ & UV 279 nm & $\mathrm{TLC}-\mathrm{H}_{2} \mathrm{SO}_{4}$ & - & TLC- $\mathrm{H}_{2} \mathrm{SO}_{4}$ \\
\hline $\begin{array}{l}\text { Metenolone } \\
\text { acetate }\end{array}$ & - & - & UV 242 nm & - & - & TLC $254 \mathrm{~nm}$ \\
\hline $\begin{array}{l}\text { Metenolone } \\
\text { enanthate }\end{array}$ & - & - & UV $242 \mathrm{~nm}$ & - & - & TLC $254 \mathrm{~nm}$ \\
\hline $\begin{array}{l}\text { Methylprednisolo- } \\
\text { ne }\end{array}$ & UV $243 \mathrm{~nm}$ & NP-HPLC 254 nm & UV 243 nm & TLC 254 nm & RP-HPLC 254 nm & TLC-tetrazolium \\
\hline -acetate & UV $243 \mathrm{~nm}$ & - & - & RP-HPLC 254 nm & - & - \\
\hline $\begin{array}{l}\text {-hydrogen } \\
\text { succinate }\end{array}$ & UV $243 \mathrm{~nm}$ & - & - & RP-HPLC 254 nm & - & - \\
\hline Methyltestosterone & UV $241 \mathrm{~nm}$ & RP-HPLC $241 \mathrm{~nm}$ & UV $241 \mathrm{~nm}$ & TLC $254 \mathrm{~nm}$ & RP-HPLC 254 nm & TLC 254 nm \\
\hline Mibolerone & - & RP-HPLC $254 \mathrm{~nm}$ & - & - & - & - \\
\hline $\begin{array}{l}\text { Mometasone } \\
\text { furoate }\end{array}$ & UV $249 \mathrm{~nm}$ & RP-HPLC 254 nm & - & RP-HPLC 254 nm & TLC $254 \mathrm{~nm}$ & - \\
\hline $\begin{array}{l}\text { Nandrolone } \\
\text { decanoate }\end{array}$ & - & RP-HPLC 240 nm & - & - & NP-HPLC 238 nm & - \\
\hline $\begin{array}{l}\text { Nandrolone } \\
\text { phenylpropionate }\end{array}$ & - & TLC 239 nm extr. & - & - & - & - \\
\hline $\begin{array}{l}\text { Norethisterone } \\
\text { (norethindrone) }\end{array}$ & Titration ethinyl & UV $240 \mathrm{~nm}$ & Titration ethinyl & TLC- $\mathrm{H}_{2} \mathrm{SO}_{4}$ & TLC- $\mathrm{H}_{2} \mathrm{SO}_{4}$ & - \\
\hline -acetate & Titration ethinyl & UV $240 \mathrm{~nm}$ & Titration ethinyl & RP-HPLC $254 \mathrm{~nm}$ & & RP-HPLC $254 \mathrm{~nm}$ \\
\hline Norethynodrel & - & UV 240 nm-HCl & - & - & TLC- $\mathrm{H}_{2} \mathrm{SO}_{4}$ & - \\
\hline Norgestimate & - & RP-HPLC 244nm & - & - & $\begin{array}{l}\text { RP-HPLC } 244 \mathrm{~nm} \\
\text { NP-HPLC } 210 \mathrm{~nm}\end{array}$ & - \\
\hline Norgestrel & Titration ethinyl & UV $241 \mathrm{~nm}$ & Titration ethinyl & TLC-phos.mol. & TLC-phos.mol. & TLC $254 \mathrm{~nm}$ \\
\hline Oxandrolone & - & Titration lactone & - & - & TLC- $\mathrm{H}_{2} \mathrm{SO}_{4}$ & - \\
\hline Oxymetholone & - & TLC $315 \mathrm{~nm}$ extr. & - & - & - & - \\
\hline $\begin{array}{l}\text { Pancuronium } \\
\text { bromide }\end{array}$ & Titration $\mathrm{HClO}_{4}$ & - & Titration $\mathrm{HClO}_{4}$ & TLC-I ${ }_{2}$ & - & TLC-NaNO $2+\mathrm{BiI}_{3}$ \\
\hline $\begin{array}{l}\text { Prasterone sodium } \\
\text { sulfate }\end{array}$ & - & - & $\begin{array}{l}\text { Ion-exchange/ } \\
\text { Titration } \mathrm{NaOH}\end{array}$ & - & - & TLC- $\mathrm{H}_{2} \mathrm{SO}_{4}$ \\
\hline Prednicarbate & RP-HPLC 243 nm & - & - & RP-HPLC 243 nm & - & - \\
\hline Prednisolone & UV $243.5 \mathrm{~nm}$ & NP-HPLC 254 nm & RP-HPLC 247 nm & RP-HPLC 254 nm & TLC $254,366 \mathrm{~nm}$ & TLC-tetrazolium \\
\hline -acetate & UV 243 nm & NP-HPLC 254 nm & RP-HPLC 254 nm & RP-HPLC 254 nm & NP-HPLC 254 nm & TLC $254 \mathrm{~nm}$ \\
\hline -hemisuccinate & - & TLC 243 nm extr. & - & - & - & - \\
\hline -pivalate & UV 243 nm & - & - & RP-HPLC 254 nm & - & - \\
\hline -sodium & UV 247 nm & UV 241 nm & - & RP-HPLC 254 nm & Prednisolone & - \\
\hline
\end{tabular}




\begin{tabular}{|c|c|c|c|c|c|c|}
\hline phosphate & & enzime, extract. & & & extraction $241 \mathrm{~nm}$ & \\
\hline $\begin{array}{l}\text {-sodium } \\
\text { succinate }\end{array}$ & - & VIS-tetrazolium & RP-HPLC $254 \mathrm{~nm}$ & - & - & - \\
\hline -succinate & - & - & RP-HPLC $242 \mathrm{~nm}$ & - & - & TLC $254 \mathrm{~nm}$ \\
\hline -tebutate & - & NP-HPLC $254 \mathrm{~nm}$ & - & - & - & - \\
\hline Prednisone & UV $238 \mathrm{~nm}$ & RP-HPLC $254 \mathrm{~nm}$ & - & RP-HPLC 254 nm & NP-HPLC 254 nm & - \\
\hline Progesterone & UV $241 \mathrm{~nm}$ & RP-HPLC $254 \mathrm{~nm}$ & UV $241 \mathrm{~nm}$ & RP-HPLC $241 \mathrm{~nm}$ & - & TLC $254 \mathrm{~nm}$ \\
\hline Rimexolone & - & RP-HPLC $242 \mathrm{~nm}$ & - & - & RP-HPLC $242 \mathrm{~nm}$ & - \\
\hline Spironolactone & UV $238 \mathrm{~nm}$ & RP-HPLC $254 \mathrm{~nm}$ & UV $238 \mathrm{~nm}$ & $\begin{array}{l}\text { RP-HPLC } \\
254 / 283 \mathrm{~nm}\end{array}$ & $\mathrm{TLC}-\mathrm{H}_{2} \mathrm{SO}_{4}$ & TLC- $\mathrm{H}_{2} \mathrm{SO}_{4}$ \\
\hline Stanozolol & Titration $\mathrm{HClO}_{4}$ & Titration $\mathrm{HClO}_{4}$ & - & TLC- $\mathrm{H}_{2} \mathrm{SO}_{4}$ & TLC- $\mathrm{H}_{2} \mathrm{SO}_{4}$ & - \\
\hline Testolactone & - & VIS-isoniazid & - & - & $\begin{array}{l}\text { TLC } 254 \mathrm{~nm}+ \\
\text { acid dichromate }\end{array}$ & - \\
\hline Testosterone & UV $241 \mathrm{~nm}$ & TLC 239 nm extr. & - & TLC $254 \mathrm{~nm}$ & - & - \\
\hline -cypionate & - & GC & - & - & - & - \\
\hline -enantate & UV $241 \mathrm{~nm}$ & VIS-isoniazid & UV $241 \mathrm{~nm}$ & $\begin{array}{l}\text { TLC- } \mathrm{H}_{2} \mathrm{SO}_{4} \\
\text { RP-HPLC } 240 \mathrm{~nm}\end{array}$ & $\begin{array}{l}\text { TLC-p-toluene } \\
\text { sulfonic acid }\end{array}$ & - \\
\hline -propionate & UV $241 \mathrm{~nm}$ & VIS-isoniazid & UV $241 \mathrm{~nm}$ & TLC $254 \mathrm{~nm}$ & - & TLC $254 \mathrm{~nm}$ \\
\hline Trenbolone acetate & - & RP-HPLC 344 nm & - & - & $\begin{array}{l}\text { TLC-phos.mol. } \\
\text { RP-HPLC } 344 \text { nm }\end{array}$ & - \\
\hline Triamcinolone & UV 238 nm & RP-HPLC 254 nm & RP-HPLC 254nm & RP-HPLC $238 \mathrm{~nm}$ & - & - \\
\hline -acetonide & UV $238.5 \mathrm{~nm}$ & RP-HPLC $254 \mathrm{~nm}$ & RP-HPLC 254nm & RP-HPLC $254 \mathrm{~nm}$ & RP-HPLC 254 nm & TLC $254 \mathrm{~nm}$ \\
\hline -diacetate & - & RP-HPLC $254 \mathrm{~nm}$ & - & - & - & - \\
\hline -hexacetonide & UV $238 \mathrm{~nm}$ & RP-HPLC $254 \mathrm{~nm}$ & - & RP-HPLC 254 nm & RP-HPLC 254 nm & - \\
\hline
\end{tabular}

and Pharm. Jp. XIV contains only a few (the formulations in Pharm. Jp. XIV are indicated by cursive letters).

A great variety of sample-preparation methods are used to assay the formulations. Solid dosage forms (tablets, etc.) are either disintegrated with water, followed by dilution with methanol, acetonitrile or the mobile phase of the RP-HPLC system, or extraction of the aqueous phase with chloroform. More common is direct extraction mainly with methanol. Direct extraction with methanol, chloroform, acetonitrile, etc. is the most widely used sample-preparation method for creams, while in addition to these, extraction with hexane, heptane, ioctane followed by extraction of the apolar phase with mixtures of water and methanol, acetonitrile, etc. is also used for ointments. Aqueous solutions are usually diluted with water or the mobile phase of the RP-HPLC method, or extracted with chloroform, ethyl acetate etc. Aqueous suspensions are homogenized by simple dilution with methanol, 2-propanol or the mobile phase of the RP-HPLC system. Oily injections are either simply diluted, mainly with chloroform or diluted with hexane, etc., followed by extraction with polar solvents or solvent mixtures.

The predominant method for the assay is reversed phase HPLC with UV detection, either at $254 \mathrm{~nm}$ or at the maximum of the UV spectra of the active ingredients. This method is used among others for the assay of aclometasone dipropionate and amcinonide cream and ointment, betamethasone cream and tablets, betamethasone benzoate gel, betamethasone dipropionate cream, ointment, lotion and topical aerosol, betamethasone sodium phosphate injection, betamethasone sodium phosphate and acetate injectable suspension, betamethasone valerate cream, ointment and lotion, clobetasol propionate cream, ointment and topical solution, cortisone acetate injectable suspension, danazol capsules, desoxycorticosterone pivalate injectable suspension, desoxymetasone cream and ointment, dexamethasone injection, ophthalmic suspension, oral solution elixir and tablets, dexamethasone acetate injectable suspension, dexamethasone sodium phosphate cream, injection, ophthalmic ointment and ophthalmic solution, dydrogesterone tablets, estradiol tablets and vaginal cream, estradiol benzoate injectable suspension, estradiol cypionate and valerate injection, estriol tablets, estrone injectable suspension, estropipate tablets and vaginal cream, ethynodiol diacetate and mestranol tablets, ethynodiol diacetate and ethinylestradiol tablets, finasteride tablets, fludrocortisone acetate tablets, flunisolide nasal solution, fluocinolone acetonide cream, ointment and topical solution, fluocinonide cream, ointment, gel and topical solution, fluorometholone ophthalmic suspension, fluoxymesterone tablets, flurandrenolide cream, lotion, tape, halcinonide cream and ointment, hydrocortisone cream, ointment, gel, lotion, rectal suspension, hydrocortisone butyrate cream, hydrocortisone valerate cream and ointment, isofluprednone acetate injectable suspension, levonorgestrel and ethinylestradiol tablets, medroxyprogesterone acetate tablets, megestrol acetate oral suspension and tablets, methylprednisolone tablets, methylprednisolone acetate injectable suspension, mometasone furoate cream, ointment and topical solution, nandrolone decanoate injection, norethindrone and ethinylestradiol tablets, norethindrone and mestranol tablets, norgestrel and ethinylestradiol tablets, prednisolone oral suspension and syrup, prednisolone tablets, prednisolone acetate injectable suspension and ophthalmic suspension, prednisone oral solution, injectable suspension and tablets, progesterone injection, injectable suspension and vaginal suppositories, rimexolone ophthalmic suspension, spironolactone tablets, spironolactone and hydrochlorothiazide tablets, triamcinolone tablets, triamcinolone acetonide cream, ointment, topical aerosol, lotion and injectable suspension, triamcinolone diacetate oral suspension, syrup and injectable suspension and triamcinolone hexacetonide injectable suspension.

Normal-phase HPLC is used for the assay of cortisone acetate tablets, diflorasone cream, drostanolone propionate ointment, fluorometholone cream, hydrocortisone tablets, hydrocortisone acetate cream, ointment and lotion, medroxyprogesterone acetate injectable suspension, prednisolone tablets and prednisolone tebutate injectable suspension.

Of the other chromatographic methods, gas chromatography is used for the assay of drostanolone propionate injection, esterified and conjugated estrogen tablets, mibolerone oral solution, oxandrolone tablets and testosterone cypionate injection. TLC separation, extraction followed by Tetrazolium 
Blue colorimetry is the assay method for betamethasone syrup and methylprednisolone acetate cream, while column chromatographic separation followed by Tetrazolium Blue colorimetry or iron-phenol colorimetry is used for the assay of dexamethasone gel and estradiol pellets and injectable suspension, respectively.

The above-discussed chromatographic methods are selective and stability indicating. The same cannot be said for the nonchromatographic methods. UV spectrophotometric assay based on natural absorption is carried out for dexamethasone sodium phosphate inhalation aerosol, dydrogesterone tablets, methyltestosterone tablets and capsules, oxymetholone tablets, prednisolone sodium phosphate injection and ophthalmic solution (after enzymatic hydrolysis and extraction), progesterone in intrauterine contraceptive system, stanozolol tablets and testosterone injectable suspension. A UV spectrophotometry is used in some other cases as well in the content uniformity and dissolution tests of tablet formulations. The selectivity of some colorimetric methods also used for the assay of steroid hormone formulations is not better either..$^{2-4,9,10}$ For example, reactions based on the condensation of the unsaturated 3-oxo group with isoniazid (clocortolone pivalate cream, hydrocortisone caproate injection, nandrolone phenylpropionate injection, norethindrone tablets, norgestrel tablets, testolactone tablets, testosterone enanthate injection and testosterone propionate injection) or 4-aminoantipyrine (flumethasone pivalate cream) measure the less vulnerable part of the molecules. The reactions of the phenol-type ring A based on diazo-coupling (estradiol benzoate injection) or on the nonstoichiometric reaction with the sulfuric acid-methanol reagent (ethinylestradiol tablets) are not stability-indicating either. The situation is somewhat better with the color reactions of corticosteroids with sensitive, reducing side chains at position 17. Most of their degradation products do not react with the alkaline Tetrazolium Blue (desoxycorticosterone acetate injection and pellets, dexamethasone topical aerosol, hydrocortisone injectable suspension and hydrocortisone acetate ophthalmic ointment and suspension, injectable suspension) or phenylhydrazine-sulfuric acid reagents (hydrocortisone sodium phosphate injection and prednisolone cream).

It is amazing that an extremely outdated and labor-extensive method is used by USP XXVI for the assay of estrone oily injection. The procedure includes three extraction steps (consuming $50 \mathrm{ml}$ of hexane, $50 \mathrm{ml}$ of benzene (!) and $95 \mathrm{ml}$ of chloroform), two evaporations to dryness, formation of hydrazone derivative with trimethylacethydrazide ammonium chloride and its decomposition. Finally the weight of estrone is measured!

\section{Spectroscopic and Spectrophotometric Methods}

\section{3·1 Ultraviolet-visible spectrophotometry}

As shown in the previous sections, in spite of its poor selectivity UV spectrophotometry is widely used for the identification and assay of bulk steroid drugs. The assay is carried out either using a reference standard material or by determining and describing the value of the specific absorbance. The validation of the determination of the latter by interlaboratory study preceded by recrystallization and checking the purity of the test sample by phase solubility analysis, HPLC and differential scanning calorimetry was described on the example of triamcinolone. ${ }^{11}$ Problems to be solved for the application of this method to the assay of drug formulations is the elimination of matrix effects and simultaneous determination of the active ingredients of two- or multicomponent formulations. In simple cases improved extraction procedure such as solid phase extraction in the case of the determination of hydrocortisone in ointments ${ }^{12}$ is sufficient. Dual-wavelength measurements can also give satisfactory results. For example, the release of hydrocortisone acetate from microcapsules in aqueous suspension was monitored at $247.6 \mathrm{~nm}$ with $277 \mathrm{~nm}$ as the reference wavelength. ${ }^{13}$ The classical dual-wavelength spectrophotometry was successfully used for the simultaneous determination of spironolactone and hydrochlorothiazide with their overlapping spectra in a tablet formulation. ${ }^{14}$ The performance of the method can be improved by multiwavelength measurements and chemometric methods. Partial least-squares regression analysis was applied to other diuretic preparations, such as spironolactone-althiazide ${ }^{15}$ and spironolactone-chlorthalidone ${ }^{16}$ formulations. The much more delicate problem of the assay of the low-dosed levonorgestrel-ethinylestradiol ${ }^{17}$ and gestodene-ethinylestradiol ${ }^{18}$ oral contraceptive tablets was also solved by the partial least-squares regression analysis. Even three-component drug formulations were successfully analyzed by this and other chemometric methods, such as the principal component regression method. One example is the mixture of hydrocortisone, nystatin and oxytetracycline. ${ }^{19}$ The accuracy and precision of the determination of even as low a quantity as 2 $\mathrm{mg} / \mathrm{vial}$ dexamethasone in the presence of 250 and $10 \mathrm{mg}$ of vitamins $\mathrm{B}_{6}$ and $\mathrm{B}_{12}$, respectively, in an injection formulation were good. ${ }^{20}$ Other 3-component formulations containing low quantities of dexamethasone resolved by partial least-squares regression analysis and other chemometric methods were Polymyxin B, trimethoprim, dexamethasone ${ }^{21}$ and chlorpheniramine, naphazoline and dexamethasone. ${ }^{22}$ In the latter case, the use of artificial neural network analysis was necessary for the determination of dexamethasone due to the non-linearity caused by interactions among the components.

Derivative UV spectrophotometry ${ }^{10}$ was also successfully applied to the analysis of steroid hormone formulations. In simple cases (single-component formulations) only the spectral background caused by the excipients should be eliminated. For this purpose first-derivative spectra are usually sufficient. An example for this is the determination of triamcinolone acetonide in an ointment. ${ }^{23}$ The same technique using the "zero-crossing" method was found to be suitable for the simultaneous determination of the components of dual-component drug formulations such as creams and tablets containing triamcinolone acetonide and terbinafine hydrochloride ${ }^{24}$ and oral contraceptives containing ethinylestradiol and levonorgestre ${ }^{25,26}$ as well as ethinylestradiol and gestodene. ${ }^{27} \mathrm{~A}$ zero-crossing second-derivative method was used for the determination of fluorometholone and tetrahydrozoline hydrochloride ${ }^{28}$ as well as estradiol and medroxyprogesterone acetate $^{29}$ in formulations. Another possibility to improve the selectivity of the method is the use of "ratio spectrum (zerocross) derivative spectroscopic" method. Examples for this are the determination of spironolactone and hydrochlorothiazide, ${ }^{14}$ hydrocortisone, nystatin and oxytetracycline, ${ }^{19}$ cyproterone acetate and estradiol valerate ${ }^{30}$ in pharmaceutical formulations. The performance of various multivariate chemometric and derivative spectrophotometric methods is compared for examples of formulations containing hydrocortisone and $\mathrm{Zn}$ Bacitracin $^{31}$ as well as dexamethasone and polymyxin B. ${ }^{32}$ An interesting feature of another method for the assay of spironolactone and hydrochlorothiazide, based on ratio spectrum derivative spectroscopy, making use of a rapidscanning diode-array spectrophotometer, is that it is adopted to 
flow-injection analysis. ${ }^{33}$

The importance of spectrophotometric/colorimetric methods based on chemical reactions has dramatically decreased in the last years both in the analysis of bulk steroid drugs and formulations made thereof. As can be seen in Table 1 and in the section "Assay of steroid hormone formulations" some of the classical reactions (e.g. condensation with isoniazid and phenylhydrazine, redox reaction with tetrazolium reagents) are still in use in some instances. Many other reactions were also described. ${ }^{2-4,9,10}$ Further research in this field can be considered to be unnecessary: publications of this kind published in the last 15 years are not referred to in this review unless these are particularly interesting. This is the case with a paper where Friedel-Crafts acetylation of steroids followed by taking the UV spectrum enables interesting discrimination to be made between various isomeric derivatives. ${ }^{34}$ Kinetic variants of the classical Blue Tetrazolium and phenylhydrazine ${ }^{35}$ and isoniazid ${ }^{36}$ reactions and their application to the analysis of corticosteroids in various pharmaceuticals are also worth mentioning.

\subsection{Fluorimetry}

The native fluorescence of estrogens enables their direct fluorimetric determination, e.g. the determination without a preliminary separation of estradiol valerate in an injection formulation in the presence of hydroxyprogesterone caproate (Ex: $295 \mathrm{~nm} / \mathrm{Em}$ : $308 \mathrm{~nm}$ ). ${ }^{37}$ However, the main application field of this is their sensitive HPLC detection.

Measurements based on fluorescence induced by nonstoichiometric reactions with various strongly acidic reagents $s^{3,4,9}$ have almost completely lost their importance in modern pharmaceutical analysis. However, as seen in the sections dealing with pharmacopoeias, methanol-sulfuric acid is still an important spray reagent in the thin-layer chromatographic analysis of steroid drugs. An interesting, highly specific and sensitive FIA method for the determination of fluticasone propionate is based on splitting with sodium hydroxide of its $-\mathrm{CO}-\mathrm{S}-\mathrm{CH}_{2} \mathrm{~F}$ side chain to form fluoromethylthiol which is further reacted with glycine and $o$-phthalaldehyde. The strongly fluorescent isoindole derivative is formed in the reaction coil of the FIA apparatus. ${ }^{38}$

\subsection{Infrared and Raman spectroscopy}

Infrared (IR) spectroscopy is the most generally used method for the identification of bulk steroid drugs in modern pharmacopoeias. $^{6-8}$ In addition to this, IR spectroscopy, especially Fourier-transform IR (FTIR) is one of the most important methods, together with X-ray powder diffractometry, differential scanning calorimetry (DSC), thermogravimetry (TGA) and thermomicroscopy to characterize the solvates and polymorphic modifications frequently occurring among steroid hormone drugs. ${ }^{39}$ One of the most characteristic examples is spironolactone, where in the early literature several polymorphs and solvates were described. Conventional IR spectrometry using fused $\mathrm{KBr}$ discs is not suitable for their differentiation due to the easy transformation of the polymorphs under pressure. On the basis of diffuse reflectance infrared Fourier transform spectroscopy (DRIFTS) and Fourier transform Raman spectroscopic investigations supported by DSC and TGA measurements ${ }^{40}$ four different polymorphic forms ${ }^{41}$ and five solvates $^{42}$ were identified and characterized. FT-IR studies combined with all of the above mentioned solid-phase techniques revealed the existence of three polymorphs of fluocinolone acetonide ${ }^{43}$ as well as two polymorphs and a hemihydrate of flunisolide. ${ }^{44}$

The DRIFTS method is also suitable for the rapid verification of identity, as well as the content of various drugs, among others finasteride in their solid formulations. ${ }^{45}$ TG/FT-IR studies supported by X-ray diffraction and DSC revealed the mechanism of the decomposition of prednisolone hemisuccinate in a freeze-dried formulation. ${ }^{46}$

Near-infrared reflectance spectroscopy has become a versatile tool in drug analysis and in-process control in drug production. It was found to be suitable to solve as delicate a problem as the simultaneous determination of norethisterone and ethinylestradiol in oral contraceptive tablets. ${ }^{47}$

\subsection{Mass spectrometry}

In the majority of cases, mass spectrometry is applied in pharmaceutical steroid analysis associated with various chromatographic techniques. Examples for these will be presented in some of the subsequent sections. Here, only one direct application is mentioned. Time-of-flight secondary ion mass spectrometry was successfully applied for the characterization and imaging of a controlled-release drug delivery system containing prednisolone sodium metasulfobenzoate. Cross sections of the device containing a multi-polymer-layer system were probed for the distribution of the active ingredient. ${ }^{48}$

\subsection{NMR spectroscopy}

One of the relatively rare direct applications of NMR spectroscopy in pharmaceutical steroid analysis is its use for the rapid screening and compositional analysis of steroid cocktails and veterinary drug formulations illegally used to livestock. Stanozolol, fluoxymesterone, methylboldenone, norethandrolone, clobestol acetate, testosterone and its cypionate and decanoate and other steroids were identified directly or after HPLC fractionation with the aid of a ${ }^{1} \mathrm{H}-\mathrm{NMR}$ database. ${ }^{49}$ When using interrupted decoupling, solid state ${ }^{13} \mathrm{C}$ NMR is suitable not only for detecting low-dose active ingredients (among others prednisolone) in solid dosage forms, but also for discrimination between the two polymorphic forms of the latter. ${ }^{50}$ Further analytical applications of NMR spectroscopy are discussed in the section dealing with HPLC.

In addition to analytical applications, NMR spectroscopy is a good tool for studying the mechanism of interactions taking place between the analyte and stationary phase. As an example, the transferred NOESY study of the interactions between various steroids and calix[8]arene-based stationary phases is mentioned. ${ }^{51}$ Similar studies related to chiral interactions are shown in the last section of this review.

\subsection{Chemiluminometry}

Although the main application field of chemiluminescence in steroid analysis is chemiluminescence immunoassay in biological-clinical analysis, there are also a few direct applications in pharmaceutical analysis. The sensitising effect of corticosteroids on the chemoluminogenic reaction between sulfite and cerium(IV) was exploited for their flow-injection (FIA) determination in pharmaceutical formulations. ${ }^{52,53} \mathrm{~A}$ luminol chemiluminescence determination for the same purpose is also described. ${ }^{54}$

\subsection{Circular dichroism (CD) spectropolarimetry}

The main application field of $\mathrm{CD}$ spectroscopy is structural analysis but this technique can be successfully used also for analytical purposes. The early literature of the applications to steroid hormone analysis was reviewed. ${ }^{55}$ Of the recent applications, two are mentioned here. The profound difference between the ellipticities of ethisterone and its 5-ene isomer 
enables their selective determination (ethisterone at $348 \mathrm{~nm}$ at its negative maximum of the $\mathrm{CD}$ spectrum) and the isomer at $296 \mathrm{~nm}$ at the positive maximum of the CD curve. When the simultaneous determination was carried out by HPLC, the spectropolarimeter could act as a CD-detector. ${ }^{56}$ The applicability of the CD method can be enhanced by the use of preliminary chemical reactions. A difference CD method was developed for the determination of 4-ene-3-oxo steroids based on oxime formation making use of the large difference between the ellipticities before and after oximation. This method was found to be suitable for the determination to as low a concentration as $0.02 \%$ of levonorgestrel acetate impurity in norgestimate. ${ }^{57}$

\section{Chromatographic and Hyphenated Methods}

\section{4·1 Planar chromatography}

In contrast to the pharmacopoeias where TLC is used only as a semi-quantitative limit test for purity check of bulk steroid hormone drugs, in the literature of the last 15 years almost exclusively quantitative densitometric methods are described for the purity check and also for the assay of steroid hormone formulations. Typical papers describing the assay of formulations are e.g., the determination of betamethasone valerate in various creams together with other active ingredients. Conventional silica gel 60 F254 plates were used; (see section "Related impurities test of bulk drug materials"). The densitograms were scanned in the reflectance mode at wavelengths which correspond to the isobestic point of the two components: $228 \mathrm{~nm}$ for betamethasone-clotrimazole cream, ${ }^{58}$ $247 \mathrm{~nm}$ for betamethasone-clioquinol $\mathrm{cream}^{59}$ and $233 \mathrm{~nm}$ for betamethasone-miconazole nitrate cream. ${ }^{60}$ The determination of the six components of conjugated estrogens in raw materials and tablet formulations was carried out after hydrolysis, extraction, followed by TLC separation and detection at 280 nm. ${ }^{61}$

If carefully validated, the quantitative TLC densitometric purity test is equivalent to the HPLC purity test. The principles and practice of validation were described taking danazol ${ }^{62}$ and estradiol benzoate ${ }^{63}$ as examples (scanning at 252 and $229 \mathrm{~nm}$, respectively).

The popularity of high-performance thin-layer chromatography (HPTLC) is continuously increasing: in the majority of papers published in the last 15 years the use of this method is reported. The advantages of this technique are clear: due mainly to the smaller particle size (about $4 \mu \mathrm{m}$ ) and narrow particle-size distribution of the stationary phases, the separation efficiency increases, enabling well-separated and wellquantifiable spots to be achieved with smaller plates, shorter running distance and shorter running time. Some of the important parameters (retention behavior, separation efficiency, selectivity) of TLC and HPTLC were compared using steroids as the model compounds. ${ }^{64}$ In the majority of cases, silica gel 60 F254 plates were used for the assay of steroid preparations. Some of the investigated formulations are as follows (the wavelength of the densitometric scan in parentheses): finasteride tablets $(228 \mathrm{~nm}),{ }^{65}$ betamethasone tablets $(245 \mathrm{~nm}),{ }^{66}$ mometasone furoate topical preparations $(260 \mathrm{~nm}),{ }^{67}$ cyproterone acetate-ethinylestradiol tablets $(284 \mathrm{~nm})^{68}$ or ethinylestradiol $(220 \mathrm{~nm})$ and cyproterone acetate $(284 \mathrm{~nm}),{ }^{69}$ dexamethasone and xylometazoline in nasal drops $(240 \mathrm{~nm}){ }^{70}$ dexamethasone sodium phosphate-neomycin sulfate solution $(246 \mathrm{~nm}),{ }^{71}$ prednisolone acetate in pharmaceutical formulations (243 nm; stepwise gradient). ${ }^{72}$ The basis for the assay of hydrocortisone, hydrocortisone acetate and clioquinol containing ointment and cream preparations was fluorescence quenching at $254 \mathrm{~nm}^{73}$ In the case of estradiol tablets (284 $\mathrm{nm})$, the HPTLC method was suitable not only for the assay but also for the detection of degradants formed under stress conditions. $^{74}$

Reversed-phase (ion pair) $\mathrm{TLC}^{74}$ and $\mathrm{HPTLC}^{75}$ systems were used for the assay of corticosteroid sodium phosphate salts in parentheral preparations and ear drops ${ }^{75}$ and various steroids, ${ }^{76}$ respectively.

Overpressured thin-layer chromatography (OPLC) is a variant of HPTLC in which the sorbent layer is covered with a pressurized elastic plate thus eliminating the vapor phase. Due to the forced flow of the eluent delivered by an automatic pump its migration velocity is constant and the migration distance can be increased up to $18 \mathrm{~cm}$ thus enabling excellent separations and improved quantifiability to be achieved. As a result of these factors, OPLC is eminently suitable for the separation of impurities and degradants in bulk drugs and their formulations. Examples for the application of OPLC to steroid hormone drugs are the purity test of norgestrel and levonorgestrel (visualization by fluorescence quenching at $254 \mathrm{~nm}$, phosphomolybdic acid or sulfuric acid), ${ }^{77}$ allylestrenol drug substance and tablet (sulfuric acid), ${ }^{78}$ nandrolone (sulfuric acid; comparison of the impurity profile with those obtained by TLC, HPLC and GC), ${ }^{79}$ norethisterone drug substance and tablet (sulfuric acid). ${ }^{80}$ OPLC was successfully used in in-process-monitoring ${ }^{81}$ and cleaning validation of equipment ${ }^{82}$ in the course of the production of bulk steroids and steroid formulations.

The usefulness of further innovations, such as temperaturecontrolled programmed TLC, ${ }^{83}$ programmed multiple development TLC with a new modification of the horizontal sandwich chamber ${ }^{84}$ and ultra-thin-layer chromatography (UTLC) where the granular adsorbents are replaced by a monolithic structure based on a silica-gel matrix has been demonstrated by using, among others, the separation of steroid mixtures. ${ }^{85}$ An interesting study dealing with the reasons for and the elimination of the irreversible adsorption of some steroids during multiple development TLC merits mentioning. ${ }^{86}$ A tandem TLC-HPLC method is described for screening cosmetic products for the presence of undeclared synthetic corticosteroids. ${ }^{87}$ Chiral selectors improved the separation of diastereomeric steroid pairs, e.g., the addition of $\beta$-cyclodextrin to the mobile phase in the case of the separation of $\mathrm{R}(+)$ - and $\mathrm{R}(-)$-budenoside on cellulose-coated HPTLC plates, ${ }^{88}$ and impregnation of the silica gel TLC plate with $d$ camphorsulfonic acid/copper(II) acetate for the separation of the diastereomeric 21-ester derivatives of prednisolone formed with racemic tetrahydrophthalic acid. ${ }^{89}$

Some papers deal with the possibilities of applying only seldom-used stationary phases e.g., Florisil, derivatized reversed-phase systems for steroid separations and with the elucidation of the separation mechanism. ${ }^{90,91}$

\subsection{Gas chromatography (GC) and GC-MS}

As already mentioned earlier in this review, and as seen in Table 1, gas chromatography does not play a very important role in the analysis of steroid hormone drugs. The reasons for this are their low volatility and (especially in the case of corticosteroids) thermal instability. In the case of sufficiently stable steroids it is a good method of choice for the assay of among others methyltestosterone (after dimethylethyl- or

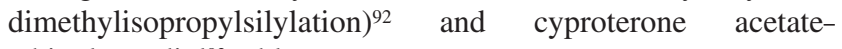
ethinylestradiol ${ }^{93}$ tablets.

GC-MS is an ideal tool for screening purposes. As many as 
134 underivatized drugs (among them 10 steroids) were included in a study to screen ethnic patent medicines available in health-food stores and ethnic markets. It is to be noted that two of the ten (dexamethasone and prednisolone) could not be detected by GC-chemical ionization MS, probably due to their vulnerable 17 -side chain. ${ }^{94}$ One possibility to enhance the applicability of GC and GC-MS to some of the thermally labile compounds is "supersonic GC-MS" using shorter capillaries with lower film thickness, an increased carrier gas flow rate and a decreased temperature. This enables several steroids (among them corticosterone with a vulnerable side chain) to be determined. ${ }^{95}$ Another screening study using GC-MS aimed at detecting anabolic steroids ${ }^{96}$ and prohormones ${ }^{97}$ in nutritional supplements.

\subsection{Supercritical fluid chromatography (SFC)}

Although the problem of thermal instability in GC can be solved by using supercritical fluid chromatography, this technique seems to have attracted little interest in steroid analysis. Several steroids were separated by SFC with lightscattering detection..$^{98,99}$ The sensitivity of the laser light scattering detector is similar to that of the UV detector with the advantage that UV-inactive steroids can also be detected with the same sensitivity. ${ }^{99}$ Examples for the use of chiral SFC will be shown in the section "Enantiomeric separations".

Supercritical fluid extraction can be a useful alternative to classical extractions as demonstrated on the examples of megestrol acetate, ${ }^{100}$ medroxyprogesterone acetate ${ }^{101}$ and cyproterone acetate ${ }^{101}$ from tablet matrices.

\section{4·4 High-performance liquid chromatography (HPLC) and HPLC-MS}

HPLC as the most important and most generally used method in pharmaceutical steroid analysis is described and characterized in the chapter "Steroid hormone drugs in pharmacopoeias", where the assay and purity test for several bulk drugs is presented in Table 1 followed by listing several formulations assayed by HPLC. Some further examples are briefly summarized here, taken from the literature where many "pharmacopoeial-like" reversed-phase HPLC assays for formulations are described (the abbreviation " $\mathrm{St}$ " in parentheses relate to stability assays). Allylestrenol- $\alpha$-tocopherol tablets, ${ }^{102}$ beclomethasone dipropionate inhalers ${ }^{103}$ and other formulations (St), ${ }^{104}$ betamethasone, its acetate and other corticosteroids in ointments, ${ }^{105,106}$ betamethasone and dexamethasone (delicate separation problem!), ${ }^{107,108}$ betamethasone-diclofenac sodium-cyanocobalamine tablet, ${ }^{109}$ cyproterone acetate tablet (St), ${ }^{110}$ dexamethasone-xylometazoline nasal drops, ${ }^{111}$ dexamethasone-retinol palmitate ointment, ${ }^{112}$ dexamethasone-trimethoprim liquid formulations, ${ }^{113}$ dexamethasone acetate-prednisolone tablet, ${ }^{114}$ estradiollevonorgestrel transdermal drug delivery formulation $(\mathrm{St}),{ }^{115}$ estradiol valerate-medroxyprogesterone acetate tablet, ${ }^{116}$ ethinylestradiol-norgestrel tablet, ${ }^{114}$ ethinylestradiollevonorgestrel and ethinylestradiol-gestodene tablets, ${ }^{117}$ finasteride tablet $(\mathrm{St}),{ }^{118}$ fluocortolone pivalate and hexanoate suppositories, ${ }^{119}$ hydrocortisone-oxytetracycline-nystatin in pharmaceutical preparations, ${ }^{120}$ hydrocortisone acetate and hemisuccinate-lidocaine in pharmaceutical preparations, ${ }^{121}$ hydrocortisone acetate-methyl- and propylparaben topical cream $(\mathrm{St}),{ }^{122}$ hydrocortisone sodium phosphate gel $(\mathrm{St}),{ }^{123}$ nestorone implants $(\mathrm{St}),{ }^{124}$ pancuronium bromide injection (St), ${ }^{125}$ prednisolone acetate-tetrahydrozoline hydrochlorideofloxacin ophthalmic preparations, ${ }^{126}$ prednisolone sodium phosphate implantable infusion pump (St), ${ }^{127}$ progesterone in micellar systems and other formulations, ${ }^{128}$ triamcinolone, its acetate and acetonide and several other corticosteroids (St), ${ }^{129}$ triamcinolone acetonide dermatological patches, ${ }^{130}$ triamcinolone acetonide, methyl- and propylparaben topical cream (St). ${ }^{131}$

Carefully validated stability-indicating HPLC methods were used for the determination of impurities and degradants in bulk pipecuronium bromide, ${ }^{132}$ budesonide, ${ }^{133}$ aqueous spironolactone- $\beta$-cyclodextrin solutions, ${ }^{134}$ and for the photodegradation kinetic study of danazol. ${ }^{135}$

HPLC is eminently suitable for screening purposes, e.g. RPHPLC for anabolic steroids, ${ }^{136}$ corticosteroids in topical pharmaceuticals using diode-array UV detector, ${ }^{137}$ toxicological analysis of steroids and other compounds with diode-array UV detector, ${ }^{138} \mathrm{NP}$ - and RP-HPLC for corticosteroids. ${ }^{139}$ Especially useful is the coupling of HPLC with mass spectrometry: a HPLC/time-of-flight MS method was developed for screening anabolic steroids in illegal cocktails, ${ }^{140}$ while for their determination in oily formulations RP-HPLC separation followed by off-line GC-MS analysis was used. ${ }^{141}$ HPLC-MS is the most suitable method for the rapid screening of highthroughput drug mixtures. ${ }^{142}$ Capillary HPLC-MALDI-TOFMS after post-column derivatization with 2,4dinitrophenylhydrazine was used for the screening of combinatorial libraries with 7 corticosteroids as model compounds. ${ }^{143}$ HPLC-MS was also used for the rapid identification of the products of biotechnological transformations. The model for this study was the hydroxylation of progesterone to $9 \alpha$-hydroxyprogesterone. ${ }^{144}$ HPLC-UV was used as the in-process-control method to follow this reaction at the industrial scale. ${ }^{145}$

On-line HPLC-NMR - although only few data are available for its use in pharmaceutical steroid analysis-is certainly the method of the future even in this field. For example, using this technique estradiol and norethisterone acetate were detected in a galenic emulsion. ${ }^{146}$ Further examples for the use of HPLC coupled with spectroscopic methods are presented in the section "Impurity and degradation profiling of steroid drugs".

In addition to the above discussed use of HPLC for the analytical investigation of bulk steroids and steroid formulations it is a useful tool also in the hands of pharmaceutical technologists to investigate drug release from various formulations and devices for controlled drug delivery. Examples are the release of prednisolone from chitosan gel beads ${ }^{147}$ or from chitosan-gelatin sponges, ${ }^{148}$ estradiol and its 3 acetate from intravaginal rings ${ }^{149}$ and triamcinolone acetonide from topical dosage forms. ${ }^{150}$

As mentioned earlier, in the majority of cases reversed-phase HPLC is used, mainly C18 columns with unbuffered binary or ternary mixtures of water with methanol, acetonitrile or tetrahydrufuran. Some innovations regarding stationary phases are as follows. Monolithic columns were found useful tools for the ultrafast separations of steroids, ${ }^{151}$ among others ingredients of a topical cream containing triamcinolone acetonide and preservatives. $^{152}$ Ultrafast analysis is also achievable by decreasing the column length with simultaneous optimization of the flow rate and gradient profile (ballistic gradients). ${ }^{153}$ Temperature-responsive stationary phases showing hydrophilic properties at lower while hydrophobic properties at higher temperatures were prepared by covalently binding poly $(N$ isopropylacrylamide) to aminopropylsilica. This is a promising tool for the temperature-controlled separation of steroids. ${ }^{154-156}$ Excellent separation of the epimers of estradiol was achieved by modifying the surface of silica gel with the covalent binding of cholesterol. $^{157}$ Molecularly imprinted artificial receptors as 
HPLC stationary phases were prepared among others for the screening of corticosteroids ${ }^{158}$ and estrogens. ${ }^{159}$ Porous graphitic stationary phases were also used for the separation of corticosteroids especially if a voltage is applied to the column, while making use of its electric conductivity. ${ }^{160}$ This technique, termed "electrochemically modulated liquid chromatography", was successfully coupled on-line with electrospray MS. ${ }^{161}$

Several papers have been published dealing with the mobile phase selection and optimation in the HPLC analysis of steroids hormone drugs. The selectivity of the separation in RP-HPLC was improved by using ternary systems containing methyl or ethyl acetate as demonstrated by the separation of $9 \alpha$ fluoroprednisolone acetate from its impurities. ${ }^{162}$ Using 2,2,2trifluoroethanol as a mobile phase component in ternary systems together with perfluorinated RP-HPLC stationary phases unique selectivity was attained explicable by the strong adsorption of the co-solvent on the surface of the stationary phase. ${ }^{163}$ Another fluorinated solvent, ethoxynonafluorobutane was introduced as an environmentally friendly and highly selective solvent in the NP-HPLC analysis of several compounds, among others steroids. ${ }^{164}$ Cyclodextrins are known to be excellent chiral selectors in enantiomeric analysis (see section "Enantiomeric analysis"). The effect of $\beta$-cyclodextrin on the retention of steroids and their separation in general ${ }^{165}$ and the effect of temperature on these characteristics ${ }^{166}$ were thoroughly studied. Chromatographic data-topological index dependence of steroids in RP-HPLC and RP-TLC are also worth mentioning. ${ }^{167}$

The use of micellar liquid chromatography, a special branch of RP-HPLC where the eluent contains very low concentration of organic modifiers (mainly 1-pentanol and acetonitrile) and about $0.1 \mathrm{M}$ sodium dodecyl sulfate (SDS) as the micelle forming agent was applied to steroid analysis by Spanish groups. ${ }^{168-176}$ This technique enables the relatively rapid analysis of derivatives with wide range of polarity with minimum need for sample preparation. In addition to retentionstructure relationship studies ${ }^{169}$ and screening of steroids, ${ }^{170-172}$ the method was successfully used for the determination of spironolactone, ${ }^{168}$ corticosteroids, ${ }^{173,176}$ methyltestosterone, ${ }^{174}$ anabolic steroids ${ }^{176}$ and danazol ${ }^{175}$ in various formulations.

Although the principles and practice of mobile phase optimization in HPLC were already set up in the early period of the history of HPLC, further studies are time to time made refining of the optimization with steroids and other compounds as the models. These include the description of a general quantitative relationship for column selectivity in RP-HPLC and the study of the effect of the change in conditions, ${ }^{177}$ the use of experimental design for spherical coordinate representations of solvent composition in RP-HPLC, ${ }^{178}$ prediction of the RP-HPLC retention of steroids using solvatochromic parameters, ${ }^{179}$ the use of $2^{3}$ factorial design and computer simulation, ${ }^{180}$ triangle optimization for the separation of finasteride and related compounds, ${ }^{181}$ the effect of the $\mathrm{pH}$ of the mobile phase for the separation of ionisable steroids, ${ }^{182}$ the effect of column overloading on the separation of mometasone furoate and clotrimazole at widely different concentrations. ${ }^{183}$

The first example for the improvements in the selectivity of the UV detection in the HPLC analysis of steroids is the detection of co-eluting species in e.g., danazol by subtracting the up-slope and down-slope diode-array spectra from the apex spectrum. ${ }^{184}$ HPLC-MS is an excellent tool for estimating minor components under overlapping peaks, e.g., the identification and quantitation of as low as $0.01 \%$ prednisolone in hydrocortisone. ${ }^{185}$ On-line post-column photochemical derivatization followed by electrochemical detection for the determination of spironolactone-hydrochlorothiazide tablets ${ }^{186}$ or diode-array UV detection for various drugs including corticosteroids in creams ${ }^{187}$ can be considered to be curiosities. Evaporative light scattering detector can be of importance in the case of UV-inactive steroids such as pancuronium bromide and related compounds. ${ }^{188}$ The native fluorescence of ethinylestradiol (ex: $285 \mathrm{~nm} / \mathrm{em}: 310 \mathrm{~nm}$ ) is used in the fluorimetric detection of the USP dissolution test of levonorgestrel-ethinylestradiol tablets $^{7}$ while terbium(III)sensitized fluorescence (ex: $245 \mathrm{~nm} / \mathrm{em}$ : $545 \mathrm{~nm}$ ) detection was described for various steroids in the course of their SDS micellar HPLC determination. ${ }^{170}$

In addition to its analytical application, HPLC is a useful tool in other fields of steroid drug research, too. For example HPLC was used for the determination of apparent association constants of steroid-cyclodextrin inclusion complexes, ${ }^{189}$ lipophilicity profiling, ${ }^{190}$ for studying drug-membrane interactions ${ }^{191}$ and high-throughput $\log P$ measurements. ${ }^{192} \quad$ Biopartitioning micellar chromatography with polyoxyethylene (23) lauryl ether (Brij35) as the micelle forming agent was used for the prediction of human drug absorption. ${ }^{193}$ Calculations based on linear solvation energy relationship were found to be useful to find "open windows" for internal standards in RP-HPLC chromatograms of various compounds, among others steroids ${ }^{194}$ and these calculations were used to find suitable internal standard for the determination of estradiol and levonorgestrel in transdermal drug delivery formulations. ${ }^{195}$

\section{Electrophoretic and Related Methods}

\subsection{Capillary electrophoresis (CE)}

Being neutral compounds the overwhelming majority of steroid hormone drugs cannot be analyzed by direct CE. This technique is restricted to ionizable derivatives. For example, the simultaneous determination of hydrocortisone 21hemisuccinate, oxytetracycline and nystatin in pharmaceutical preparations was carried out at $\mathrm{pH} 11 .{ }^{196}$ Covalent derivatization with electrically charged reagents, e.g. ketosteroids with Girard P or T reagents is a solution for this problem: the Girard hydrazones of 4-ene-3-oxo- and 17 oxosteroids can easily be separated and quantificated. ${ }^{197}$

Capillary electrophoresis can be a useful tool for the preconcentration of different classes of steroids, making use of electroosmotic flow and capillaries partially filled with various reagents, e.g., borate for the complexation of steroids with proximal hydroxyls, high $\mathrm{pH}$ buffers for weakly acidic estrogens, micelle forming agents for hydrophobic steroids. ${ }^{198}$

\section{5·2 Micellar electrokinetic chromatography (MEKC)}

MEKC is an ideal tool for the separation and quantification of lipophilic steroid drugs which cannot be directly analyzed by CE: these (mainly corticosteroids) were among the first models investigated after the invention of this new technique at the mid 1980s. ${ }^{199-201}$ Since then, great many papers have been published on this topic. Based on these, it is predictable that due to the minimum requirements of sample pretreatment, low costs and high speed MEKC can be a real alternative to HPLC in steroid analysis as demonstrated in a comparative study using betamethasone dipropionate, clotrimazole and their related substances as the model compounds. ${ }^{202}$

Some of the several new applications of MEKC to pharmaceutical steroid analysis are listed here: the determination of ethinylestradiol and levonorgestrel ${ }^{203}$ or gestodene $^{204}$ in oral contraceptives, hydrocortisone and its acetate together with various antibiotics, ${ }^{205}$ prednisolone, $\mathrm{Zn}$ - 
bacitracin and phenylephrine in ointments and ocular drops, ${ }^{206}$ prednisolone acetate, sulfacetamide and phenylephrine in local pharmaceutical preparations, ${ }^{207}$ dexamethasone, trimethoprim and polymyxin $\mathrm{B}$ in various formulations, ${ }^{208}$ betamethasone in dissolution tests. ${ }^{209}$

In the above-listed studies (and the majority of those not mentioned here) sodium dodecyl sulfate (SDS) was used as micelle forming agent in the background electrolyte. In a few cases, bile salts were also used. ${ }^{199,209}$ A comparison of the two systems using corticosteroids as the model compounds is also described. ${ }^{210}$ High concentrations of organic solvents (up to $50 \%$ acetonitrile or methanol) in the background electrolyte containing SDS enables ionic (benzalkonium chloride) and nonionic (beclomethasone dipropionate, 2-phenylethanol) compounds to be determined within one electrokinetic run. ${ }^{211}$ Using a related method, termed hydrophobic interaction electrokinetic chromatography seven active ingredients of an ointment (among them hydrocortisone) were separated and quantitated. The migration behavior of the hydrophobic and ionic constituents was influenced by the concentration of tetradecyl ammonium bromide and ammonium chloride, respectively. ${ }^{212}$ On-line sample preconcentration (370-fold improvement in detector response) was achieved for steroids by sweeping with anionic-zwitterionic micelles. ${ }^{213}$

Chiral aspects of MEKC are shown in the section "Enantiomeric analysis".

\subsection{Microemulsion electrokinetic chromatography (MEEKC)}

Although in an early study better separation characteristics were attained for steroids with MEEKC than with the related technique MEKC, this method does not seem to have been used as extensively in the practice as MEKC. In this study SDS or glycodeoxycholate were used as the micelle forming agent in MEKC and various higher alcohols, $n$-hexane, cyclohexane, etc. with SDS as the emulsion-forming solvents. ${ }^{214}$ In some further studies aiming at comparing the selectivities of the two techniques among many other compounds some steroids were also included. ${ }^{215-217}$ A good correlation was found between the retention characteristics of betamethasone and its esters and the respective $\log P_{\text {ow }}$ values $;{ }^{218}$ MEEKC is a good tool for the rapid estimation of $\log P_{\text {ow }}$ values of a wide range of compounds, among them steroid hormone drugs. ${ }^{219}$

\subsection{Capillary electrochromatography (CEC) and CEC-MS}

$\mathrm{CEC}$, which can be considered to be the combination of RPHPLC and CE, has been successfully applied to separation and quantitation of steroid drugs. The performance of HPLC, MEKC and CEC was compared using six steroids (androst-4ene-3,17-dione, testosterone, norethisterone, progesterone and the $17-\mathrm{OH}$ and $20-\mathrm{OH}$ derivative of the latter). Higher peak efficiencies were obtainable by MEKC and CEC. ${ }^{220}$ With an inhouse packing method of capillaries up to 190.000 plates per meter was achieved. ${ }^{221}$ High-temperature CEC and temperature programming resulted in a considerable reduction of the separation run time of steroids, and the latter may be a good alternative to solvent programming. ${ }^{222}$ Usually ODS phases are used for steroid separations but the successful use of macroporous, spherical polystyrene-divinylbenzene stationary phase was also described. ${ }^{223}$ Of the practical applications the rapid analysis of norgestimate and its degradants, ${ }^{224}$ tipredane and related impurities ${ }^{225}$ and fluticasone propionate and related impurities $^{226}$ is mentioned. An example for chiral CEC is presented in the section "Enantiomeric analysis".

The very promising possibilities of the new technique CEC-
MS have been reviewed with several examples from steroid drugs.227 The identification of impurities in fluticasone propionate $^{228}$ and the combination of CEC with nanospray MS with detection limits of $50 \mathrm{fg}$ for corticosteroids merit special attention. 229

\section{Electroanalytical Methods}

A review of electroanalytical methods in steroid analysis was published in 1989.230 These methods have never played very important role in this field but sufficiently sensitive and selective methods are often published up to the present time mainly for the assay of formulations. In the majority of cases differential pulse polarography, based on the reduction of the 4ene-3-oxo group is used, for e.g. spironolactone, ${ }^{231}$ beclomethasone dipropionate, ${ }^{232}$ dexamethasone sodium phosphate $^{233}$ and betamethasone valerate. ${ }^{234}$ Gestodene was determined in oral contraceptives by square-wave voltammetry and adsorptive stripping techniques. ${ }^{235}$

A direct potentiometric method was developed for muscle relaxant quaternary ammonium compounds, among them pancuronium bromide, based on ion-selective membrane electrodes prepared from ion pairs with tetraphenylborate or dipicrylaminate as the counter ions in a PVC matrix. ${ }^{236}$

\section{Selected Analytical Tasks}

7·1 Impurity and degradation profiling of steroid drugs ${ }^{237,238}$ Impurity and degradation profiling i.e. detection, identification/structure elucidation and quantitative determination of impurities and degradants usually require the complex application of one or two separation method and at least 2 - 3 spectroscopic techniques (usually UV, MS, NMR) either off-line but preferably on-line.

Of the innumerable studies, a few resulting in interesting structures are listed here beginning with corticosteroids. Six synthesis-related impurities were identified in prednisolone. ${ }^{239}$ Several synthesis-related impurities ${ }^{240,241}$ and degradants ${ }^{242,243}$ (mainly products of intramolecular oxido-reduction reactions were identified in the course of the stress stability test of mazipredone (21-deoxy-21- $N$-methylpiperazinyl derivative of prednisolone). Among minor impurities the $9 \alpha$-bromo analogue of the parent drug was found as the main impurity in triamcinolone acetonide. ${ }^{244}$ Of the other corticosteroids several synthesis-related impurities and degradants were identified in dexamethasone. ${ }^{245,246}$ Of these, the $17 \beta$-carboxy-17 $\alpha$-formyloxy derivative forming under storage conditions via a mixed anhydride is especially interesting. ${ }^{246}$ The structure elucidation of impurities in fluticasone propionate (among others an interesting -S-S- bridged dimer) is a good example for the application of new techniques such as CEC-MS 228 and on-line HPLC-NMR. ${ }^{247}$ The light-induced degradation of methylprednisolone suleptamate lead to interesting, unpredictable structures. ${ }^{248}$ Of the (contraceptive) gestogens (norethisterone, norgestrel) by-products of their ethinylation step, ${ }^{240,249}$ oxidative degradation products of these ${ }^{250}$ and of nestorone ${ }^{239}$ are described. $Z$ and $E$ isomers of the 17-(3'acetoxy- $2^{\prime}$-butenoate $)^{251,252}$ and 17 -(3-oxo-butenoate) ${ }^{1}$ identified in ethynodiol diacetate are by-products of the acetylation of the $17-\mathrm{OH}$ group. Impurities found in allylestrenol originate from its total synthesis. ${ }^{240}$

Two estrogens are also worth mentioning. In the course of the impurity profiling of estradiol HPLC-UV played predominant 
role, ${ }^{253}$ while HPLC-NMR and HPLC-MS were necessary to determine the structures of five most interesting structures (a hydroperoxide and four different dimers) in the course of oxidative and light-stress studies of ethinylestradiol. ${ }^{254}$

Of the other hormonal drugs, several impurities originating from the Birch reduction step were identified in norethisterone, ${ }^{239,250}$ an isomeric impurity in danazol ${ }^{255}$ and several oxidative degradation products in tipredane. ${ }^{225,256}$ Of the non-hormonal steroid drugs pipecuronium bromide is mentioned. An oxidative degradation product ${ }^{243,251}$ and synthesis-related impurities were identified and quantificated by NP-HPLC, ${ }^{132}$ NP-ion-pairing HPLC ${ }^{257}$ and the oxidative degradant also by quantitative NMR spectroscopic measurement. ${ }^{251}$

\subsection{Enantiomeric analysis}

Although steroid hormone drugs usually contain 6-7 chiral centers, their configuration is fixed in natural steroids and the semi-synthetic drugs prepared from them. For this reason enantiomeric analysis is not necessary in the overwhelming majority of cases. The only important exception is the total synthetically prepared norgestrel, which is mainly administered as enantiomerically pure levonorgestrel, and also (at a decreasing extent) as the racemate. Several papers have been published on the separation of the enantiomers of norgestrel. Only a few of these deal with the determination of the enantiomeric purity of levonorgestrel. In the first validated method RP-HPLC with $\gamma$-cyclodextrin in the mobile phase was used and a limit of quantitation of $0.1 \%$ dextronorgestrel was achieved. ${ }^{258}$ (With $\beta$-cyclodextrin fairly good separation is achievable at $0^{\circ} \mathrm{C}$ only. ${ }^{259}$ Using $\alpha_{1}$-acid glycoprotein (Chiral AGP) column for the HPLC separation good separation was obtained, ${ }^{260,261}$ but the limit of quantitation was inferior $(0.6 \%){ }^{260}$

Norgestrel is an excellent model compound for testing the separation efficiency of various enentioselective chromatographic and related techniques. For this reason many papers contain data for norgestrel, usually among many other model compounds. Acceptable to excellent separation was achieved using Chiralcel-OJ, ${ }^{262}$ cellulose tris(3,5dichlorophenylcarbamate), ${ }^{261}$ amylose tris(3,5-dimethylphenylcarbamate), ${ }^{263,264}$ and covalently bonded $\beta$-cyclodextrin, ${ }^{265-267}$ even bonded to a monolithic silica column. ${ }^{267}$ SFC using immobilized polysiloxane-anchored permethyl- $\beta$-cyclodextrin $(\text { Chirasil-Dex) })^{268}$ and teicoplanin or its aglycone (Chirobiotic T or TAG) ${ }^{269}$ was also used to separate the enantiomers of norgestrel. The above-mentioned cellulose tris(3,5-dichlorophenylcarbamate) and amylose tris(3,5-dimethylphenylcarbamate) were successfully used for CEC separation of the enantiomers. ${ }^{270,271}$ A comparison of the latter in the HPLC and CEC modes revealed significant advantages of CEC. ${ }^{271}$ This chiral selector was successfully used also for the HPLC separation of as many as 26 steroid enantiomeric pairs including estradiol, estrone, ethinylestradiol, nandrolone, etc. ${ }^{263,264}$

${ }^{1} \mathrm{H}-\mathrm{NMR}$ was found to be an excellent tool for modelling interactions between norgestrel enantiomers and cyclodextrins, thus creating the possibility to find a correlation between the NMR and RP-HPLC data. ${ }^{272}$ In addition to this, NMR spectroscopy using $\gamma$-cyclodextrin ${ }^{273}$ or the lanthanide shift reagent praseodymium tris[3-heptafluoropropylhydroxymethylene)-(+)-camphorate $]^{260}$ was found to be suitable for estimating the enantiomeric purity of levonorgestrel without separation. The limit of detection is somewhat higher than that achievable by HPLC.

\section{References}

1. M. Babják, G. Balogh, M. Gazdag, and S. Görög, J. Pharm. Biomed. Anal., 2002, 29, 1153.

2. S. Görög and Gy. Szász, "Analysis of Steroid Hormone Drugs", 1978, Elsevier, Amsterdam.

3. S. Görög, "Quantitative Analysis of Steroids", 1983, Elsevier, Amsterdam.

4. S. Görög (ed.), "Steroid Analysis in the Pharmaceutical Industry", 1989, Ellis Horwood, Chichester.

5. H. L. Makin , D. B. Gower, and D. N. Kirk (ed.), "Steroid Analysis", 1995, Blackie, Glasgow.

6. European Pharmacopoeia 4, Council of Europe, Strasbourg, 2002.

7. United States Pharmacopoeia 26, USP Convention Inc., Rockville, 2003.

8. The Japanese Pharmacopoeia 14th Edition, Society of Japanese Pharmacopoeia, Tokyo, 2001.

9. J. Bartos and M, Pesez, "Colorimetric and Fluorimetric Analysis of Steroids", 1976, Academic Press, London.

10. S. Görög, "Ultraviolet-Visible Spectrophotometry in Pharmaceutical Analysis", 1995, CRC Press, Boca Raton, $323-334$.

11. U. Rose and J. Fuchs, Pharmeuropa, 1998, 10, 146.

12. D. Bonazzi, V. Andrisano, R. Gatti, and V. Cavrini, J. Pharm. Biomed. Anal., 1995, 13, 1321.

13. M. L. Shively and A. P. Simonelli, Int. J. Pharm., 1989, 50, 39.

14. N. Erk, Anal. Lett., 1999, 32, 1371.

15. M. S. Linares, J. M. G. Fraga, A. I. Jimenez, F. Jimenez, and J. J. Arias, Anal. Lett., 1999, 32, 2489.

16. M. L. Luis, J. M. Garcia, A. I. Jimenez, F. Jimenez, and J. J. Arias, JAOAC Internat., 1999, 82, 1054.

17. J. J. Berzas, J. Rodríguez Flores, and G. Castañeda, Anal. Chim. Acta, 1997, 340, 257.

18. J. J. Berzas, J. Rodríguez, and G. Castañeda, Anal. Sci., 1997, 13, 1029.

19. J. M. Lemus Gallego and J. Pérez Arroyo, Anal. Chim. Acta, 2002, 460, 85.

20. A. J. Nepote, P. C. Damiani, and A .C. Olivieri, J. Pharm. Biomed. Anal., 2003, 31, 621.

21. J. M. Lemus Gallego and J. Pérez Arroyo, Anal. Chim. Acta, 2001, 437, 247.

22. H. C. Goicoechea, M. S. Collado, M. L. Satuf, and A. C. Olivieri, Anal. Bioanal. Chem., 2002, 374, 460.

23. E. R. M. Kedor-Hackmann, E. A. S. Gianottto, and M. I. R. M. Santoro, Anal. Lett., 1997, 30, 1861.

24. Y. S. El-Saharty, N. Y. Hassan, and F. H. Metwally, J. Pharm. Biomed. Anal., 2002, 28, 569.

25. J. J. Berzas, J. Rodríguez, and G. Castañeda, Analyst, 1997, $122,41$.

26. S. Tatar and S. Atmaca, Pharmazie, 1996, 51, 4.

27. J. J. Berzas, J. Rodríguez, G. Castañeda, and F. J. Guzmán Bernardo, Anal. Lett., 1997, 30, 2221.

28. T. G. Altuntas, F. Korkmaz, and D. Nebioglu, Pharmazie, 2000, 55, 1 .

29. M. I. Toral, C. Soto, P. Richter, and A. E. Tapia, JAOAC Internat., 2002, 85, 883.

30. E. Dinç, C. Yücesoy, Í. Murat Palabıyık, Ö. Üstündağ, and F. Onur, J. Pharm. Biomed. Anal., 2003, 32, 1.

31. J. M. Lemus Gallego and J. Pérez Arroyo, Microchim. Acta, 2003, 141, 133.

32. J. M. Lemus Gallego and J. Pérez Arroyo, Anal. Lett., 2001, 34, 1265. 
33. E. Martín, O. Hernández, J. J. Arias, and A. I. Jiménez, Microchem. J., 1997, 56, 207.

34. J. Studer, N. Purdie, and J. A. Krouse, Appl. Spectrosc., 2003, 57, 791.

35. L. Ayllón, M. Silva, and D. Pérez-Bendito, J. Pharm. Sci., $\mathbf{1 9 9 4}, 83,1135$.

36. M. Blanco, J. Coello, H. Iturriaga, S. Maspoch, and N. Villegas, Analyst, 1999, 124, 911.

37. D. N. Xie, J. H. Ge, Q. T. Lan, and R. G. Yu, Zhongguo Yaoke Daxue Хиebao, 1992, 23, 122.

38. C. Vannecke, A. Nguyen Minh Nguyet, M. S. Bloomfield, A. J. Staple, Y. Vander Heyden, and D. L. Massart, J. Pharm. Biomed. Anal., 2000, 23, 291.

39. E. G. Salole, in "Advances in Steroid Analysis '90", ed. S. Görög, 1991, Akadémiai Kiadó, Budapest, 473.

40. G. A. Neville, H. D. Beckstead, and J. D. Cooney, Fresenius J. Anal. Chem., 1994, 349, 746.

41. G. A. Neville, H. D. Beckstead, and H. F. Shurvell, J. Pharm. Sci., 1992, 81, 1141.

42. H. D. Beckstead, G. A. Neville, and H. F. Shurvell, Fresenius J. Anal. Chem., 1993, 345, 727.

43. M. Bartolomei, M. C. Ramusino, and P. Ghetti, J. Pharm. Biomed. Anal., 1997, 15, 1813.

44. M. Bartolomei, J. Pharm. Biomed. Anal., 2000, $24,81$.

45. J. A. Ryan, S. V. Compton, M. A. Brooks, and D. A. C. Compton, J. Pharm. Biomed. Anal., 1991, 9, 303.

46. S. Claussen, M. Böse, and M. Dittgen, Pharmazie, 2001, $56,475$.

47. P. Corti, E. Dreassi, G. Corbini, S. Lonardi, and S. Gravina, Analusis, 1990, 18, 112

48. A. M. Belu, M. C. Davies, J. M. Newton, and N. Patel, Anal. Chem., 2000, 72, 5625.

49. A. Lommen, R. Schilt, J. Weseman, A. H. Roos, J. W. van Velde, and M. W. F. Nielen, J. Pharm. Biomed. Anal., 2002, 28, 87.

50. P. J. Saindon, N. S. Cauchon, P. A. Sutton, C.-J. Chang, G. E. Peck, and S. R. Byrn, Pharm. Res., 1993, 10, 197.

51. U. Skogsberg, H. Händel, E. Gesele, T. Sokolliess, U. Menyes, T. Jira, U. Roth, and K. Albert, J. Sep. Sci., 2003 , $26,1119$.

52. I. I. Koukli and A. C. Calokerinos, Analyst, 1990, 115, 1553.

53. N. T. Deftereos and A. C. Calokerinos, Anal. Chim. Acta, 1994, 290, 190.

54. Y. Iglesias, C. Fente, B. I Vazquez, C. Franco, A. Cepeda, and S. Mayo, Anal. Chim. Acta, 2002, 468, 43.

55. A. Gergely, in "Analytical Applications of Circular Dichroism”, ed. N. Purdie and H. G Brittain, 1994, Elsevier, Amsterdam, 293.

56. D. Szegvári, P. Horváth, A. Gergely, S. Németh, and S. Görög, Anal. Bioanal. Chem., 2003, 375, 713.

57. A. Szentesi, A. Gergely, P. Horváth, and Gy. Szász, Fresenius' J. Anal. Chem., 2000, 368, 384.

58. G. Indrayanto, L. Aditama, W. Tanudjaja, and S. Widjaja, J. Planar Chrom., 1998, 11, 201.

59. G. Indrayanto, I. Wahyuningsih, and R. J. Salim, J. Planar Chrom., 1997, 10, 204.

60. G. Indrayanto, S. Widjaja, and S. Sutiono, J. Liq. Chromatogr. Relat. Technol., 1999, 22, 143.

61. J. Novaković, D. Agbaba, S. Vladimirov, and D. ŽivanovStakić, J. Pharm. Biomed. Anal., 1990, 8, 253.

62. K. Ferenczi-Fodor, Z. Végh, and Z. Pap-Sziklay, J. Planar Chrom., 1993, 6, 198.

63. K. Ferenczi-Fodor, A. Nagy-Turák, and Z. Végh, J. Planar Chrom., 1995, 8, 349.
64. H. E. Hauck, A. Junker-Buchheit, and R. Wenig, $L C-G C$ Int., 1995, 8, 34.

65. S. N. Meyyanathan, G. V. S. Ramasarma, and B. Suresh, J. Planar Chrom., 2001, 14, 188.

66. L. Wulandari and G. Idrayanto, J. Liq. Chrom. Rel. Technol., 2003, 26, 2709.

67. L. Wulandari, T. K. Sia, and G. Idrayanto, J. Liq. Chrom. Rel. Technol., 2003, 26, 109.

68. J. Novaković, I. Němcová, and M. Vaštová, J. Planar Chrom., 1990, 3, 407.

69. K. Pavić, O. Čudina, D. Agbaba, and S. Vladimirov, J. Planar Chrom., 2003, 16, 45.

70. D. Agbaba, Z. Milojevic, S. Eric, M. Aleksic, G. Markovic, and M. Solujic, J. Planar Chrom., 2001, 14, 322.

71. D. Agbaba, S. Eric, G. Markovic, V. Nedeljkovic, S. Veselinovic, and M. Vucetic, J. Planar Chrom., 2000, 13, 333.

72. G. Matysik, J. Toczolowski, and A. Matysik, Chromatographia, 1995, 40, 737.

73. J. Sherma, B. P. Whitcomb, and K. Brubaker, J. Planar Chrom., 1990, 3, 189.

74. P. N. Kotyiyan and P. R. Vavia, J. Pharm. Biomed. Anal., 2000, 22, 667.

75. K. Datta and S. K. Das, J. Planar Chrom., 1993, 6, 204.

76. H. Lamparczyk, R. J. Ochoczka, P. Zarzycki, and J. P. Zieliński, J. Planar Chrom., 1990, 3, 34.

77. K. Ferenczi-Fodor, S. Mahó, S. Pap-Sziklay, I. Török, and L. Borka, Pharmeuropa, 1997, 9, 736.

78. A. Wiszkidenszky, S. Mahó, Z. Végh, and K. FerencziFodor, J. Planar Chrom., 1998, 11, 463.

79. B. Bagócsi, D. Fábián, A. Laukó, M. Mezei, S. Mahó, Z. Végh, and K. Ferenczi-Fodor, J. Planar Chrom., 2002, 15 , 252.

80. B. Bagócsi, G. Rippel, M. Mezei, Z. Végh, and K. Ferenczi-Fodor, J. Planar Chrom., 2003, 16, 359.

81. A. Kassai, A. Szécsi, A. Koppány, Z. Végh, and K. Ferenczi-Fodor, J. Planar Chrom., 2000, 13, 30.

82. Z. Katona, L. Vincze, Z. Végh, Á. Trompler, and K. Ferenczi-Fodor, J. Pharm. Biomed. Anal., 2000, 22, 252.

83. P. K. Zarzycki, J. Chromatogr. A, 2002, 971, 193.

84. M. Matyska, A.-M. Siouffi, and E. Soczewinski, J. Planar Chrom., 1991, 4, 255.

85. H. E. Hauck, O. Bund, W. Fischer, and M. Schulz, J. Planar Chrom., 2001, 14, 234.

86. K. Ferenczi-Fodor, A. Laukó, A. Wiszkidenszky, Z. Végh, and K. Újszászy, J. Planar Chrom., 1999, 12, 30.

87. L. Gagliardi, D. de Orsi, M. R. del Giudice, F. Gatta, R. Porrà, P. Chimenti, and D. Tonelli, Anal. Chim. Acta, 2002, 457, 187.

88. J. Krzek, U. Hubicka, M. Dabrowska-Tylka, and E. Leciejewicz-Ziemecka, Chromatographia, 2002, 56, 759.

89. E. Olszewska, W. Kroszczynski, M. Lypacewicz, and T. Wasiak, Acta Chrom., 2002, 12, 219.

90. M. Waksmundzka-Hajnos, A. Petrucznik, and A. Hawryl, Chem. Anal., 2003, 48, 453.

91. M. Waksmundzka-Hajnos, M. L. Bieganowska, and A. Petrucznik, J. Planar Chrom., 1992, 5, 446.

92. N. A. Zakhari, M. I. Walash, M. S. Rizk, S. S. Toubar, C. J. W. Brooks, and W. J. Cole, J. Pharm. Biomed. Anal., 1991, 9, 705 .

93. J. Novakovic, E. Tvrzicka, and A. Pisarikova, Anal. Lett., 1991, 24, 1559.

94. R. Hsu and A. M. Au, Bull. Environ. Contam. Toxicol., 2001, 66, 178 .

95. A. B. Fialkov, A. Gordin, and A. Amirav, J. Chromatogr. 
A, 2003, 991, 217

96. K. J. S. De Cock, F. T. Delbeke, P. Van Eenoo, N. Desmet, K. Roels, and P. De Backer, J. Pharm. Biomed. Anal., 2001, 25, 843 .

97. F. T. Delbeke, P. Van Eenoo, W. Van Thuyne, and N. Desmet, J. Steroid Biochem. Mol. Biol., 2003, 83, 245.

98. Alltech Application Note, 0047E, May 2000, 2.

99. J. S. Loran and K. D. Cromie, J. Pharm. Biomed. Anal., 1990, 7, 607.

100. J. R. Dean and J. Lowdon, Analyst, 1993, 118, 747.

101.Y. Yamini, M. Asghari-Khiavi, and N. Bahramifar, Talanta, 2002, 58, 1003.

102.L. Zivanovic, L. Vojvodic, P. Ristic, M. Zecevic, and I. Nemcova, Biomed. Chromatogr., 2000, 14, 56.

103. M. LeBelle, R. K. Pike, S. J. Graham, E. D. Ormsby, and H. A. Bogard, J. Pharm. Biomed. Anal., 1996, 14, 793.

104. D. De Orsi, L. Gagliardi, F. Chimenti, and D. Tonelli, Anal. Lett., 1995, 28, 1655.

105. J. E. Kountourellis, C. K. Markopoulou, K. O. Ebete, and J. A. Stratis, J. Liq. Chromatogr., 1995, 18, 3507.

106. R. D. Marini, A. Pantella, M. A. Bimazubute, P. Chiap, P. Hubert, and J. Crommen, Chromatographia, 2002, 55, 263.

107. K.-R. Liu, S.-H. Chen, S.-M. Wu, H.-S. Kou, and H.-L. Wu, J. Chromatogr. A, 1994, 676, 455.

108. A. Santos Montes, A. I. Gasco Lopez, and R. Izquierdo Hornillos, Chromatographia, 1994, 39, 539.

109.L. González, G. Yuln, and M. G. Volonté, J. Pharm. Biomed. Anal., 1999, 20, 487.

110. A. Segall, M. Vitale, V. Pérez, F. Hormaechea, M. Palacios, and M. T. Pizzorno, Drug Dev. Int. Pharm., 2000, 26, 867.

111.Z. Milojevic, D. Agbaba, S. Eric, D. Boberic-Borojevic, P. Ristic, and M. Solujic, J. Chromatogr. A, 2002, 949, 79.

112.J. P. Surmann, B. Strahl, and C. Hock, Pharmazie, 1994, 49, 139.

113.J. M. Lemus Gallego and J. Pérez Arroyo, J. Pharm. Biomed. Anal., 2002, 30, 1255.

114.M. I. R. M. Santoro, E. B. Govato, and E. R. M. Hackmann, Anal. Lett., 1993, 26, 925.

115. J. Li, J. Pharm. Sci., 2002, 91, 1873.

116. A. Segall, F. Hormaechea, M. Vitale, V. Pérez, and M. T. Pizzorno, J. Pharm. Biomed. Anal., 1999, 19, 803.

117. M. I. R. M. Santoro, N. M. Kassab, M. Hasegawa, and E. R. M. Kedor-Hackmann, Drug Dev. Ind. Pharm., 2002, 28, 741.

118. A. A. Syed and M. K. Amshumali, J. Pharm. Biomed. Anal., 2001, 25, 1015.

119. O. Cudina, J. Brboric, Z. Vujic, D. Radulovic, and S. Vladimirov, Farmaco, 2000, 55, 125.

120.J. M. Lemus Gallego and J. Pérez Arroyo, Chromatographia, 2002, 55, 749.

121. J. M. Lemus Gallego and J. Pérez Arroyo, Anal. Bioanal. Chem., 2002, 374, 282.

122. R. Hájková, P. Solich, J. Dvořak, and J. Šicha, J. Pharm. Biomed. Anal., 2003, 32, 921.

123. M. J. Galmier, E. Beyssac, J. Petit, J. M. Aiache, and C. Lartigue, J. Pharm. Biomed. Anal., 1999, 20, 405.

124. S. M. Ahmed, F. Arcuri, F. Li, A. J. Moo-Young, and C. Monder, Steroids, 1995, 60, 534.

125.M. Zecevic, Lj. Zivanovic, and A. Stojkovic, J. Chromatogr., 2002, 949, 61.

126. M. S. Ali, M. Ghori, and A. Saeed, J. Chromatogr. Sci., 2002, 40, 429.

127.W. J. Bachman and J. G. Gambertoglio, Anal. Lett., 1990, 23, 893.
128. V. Pucci, F. Bugamelli, R. Mandrioli, B. Luppi, and M. A. Raggi, J. Pharm. Biomed. Anal., 2003, 30, 1549.

129. R. Gonzalo-Lumbreras, A. Santos-Montes, E. GarciaMoreno, and R. Izquierdo-Hornillos, J. Chromatogr. Sci., 1997, 35, 439 .

130.P. A. D. Edwardson and R. S. Gardner, J. Pharm. Biomed. Anal., 1990, 8, 935.

131.L. Matysová, R. Hájková, J. Šicha, and P. Solich, Anal. Bioanal. Chem., 2003, 376, 440.

132.G. Szepesi, M. Gazdag, and K. Mihályfi, J. Chromatogr., 1989, 464, 265.

133. S. Hou, M. Hindle, and P. R. Byron, J. Pharm. Biomed. Anal., 2001, 24, 371.

134.A. M. Kaukonen, P. Vuorela, H. Vuorela, and J.-P. Mannermaa, J. Chromatogr., A, 1998, 797, 271.

135.E. A. Gad Kariem, M. A. Abounassif, M. E. Hagga, and H. A. Al-Khamees, J. Pharm. Biomed. Anal., 2000, 23, 413.

136.R. Gonzalo-Lumbreras and R. Izquierdo-Hornillos, J. Chromatogr. B, 2000, 742, 1.

137.J. C. Reepmeyer, J. Liq. Chromatogr. Relat. Technol., 2001, 693.

138. M. Herzler, S. Herre, and F. Pragst, J. Anal. Toxicol., 2003 , 27, 233.

139.L. Valvo, A. Paris, A. L. Savella, B. Gallinella, and E. Ciranni Signoretti, J. Pharm. Biomed. Anal., 1994, 12, 805.

140. M. W. F. Nielen, J. P. C. Vissers, R. E. M. Fuchs, J. W. van Velde, and A. Lommen, Rapid Commun. Mass Spectrom., 2001, 15, 1577.

141.D. Hooijerink, R. Schilt, E. van Bennekom, and B. Brouwer, Analyst, 1994, 119, 2617.

142. K. Yu and M. Balogh, LC-GC North America, 2001, 19, 60.

143.S. Brombacher, S. J. Owen, and D. A. Volmer, Anal. Bioanal. Chem., 2003, 376, 773.

144.J. Lindholm, D. Westerlund, K.-E. Karlsson, K. Caldwell, and T. Forstedt, J. Chromatogr. A, 2003, 992, 85.

145.J. Lindholm, M. Johansson, and T. Forstedt, $J$. Chromatogr. B, 2003, 791, 323.

146. T. Glaser and K. Albert, J. Sep. Sci., 2002, 25, 393.

147.K. Kofuji, T. Ito, Y. Murata, and S. Kawashima, Biol. Pharm. Bull., 2001, 24, 205; Biol. Pharm. Bull., 2002, 25 , 268.

148. C. C. Leffler and B. W. Müller, S. T. P. Pharma Sci., 2000, 10,105 .

149.J. A. Russel, R. K. Malcolm, K. Campbell, and A. D. Woolfson, J. Chromatogr. B, 2000, 744, 157.

150.P. R. Rege, V. D. Vivivalam, and C. C. Collins, J. Pharm. Biomed. Anal., 1998, 17, 1225.

151.J. K. Lim, M. C. Riley, and S. T. Watts, LC-GC North America, 2003, 21, 47.

152.D. Šatinski, J. Hulcová, P. Solich, and R. Karliček, J. Chromatogr. A, 2003, 1015, 239.

153.L. A. Romanyshyn and P. R. Tiller, J. Chromatogr. A, 2001, 928, 41.

154.H. Kanazawa, K. Yamamoto, Y. Matsushima, N. Takai, A. Kikuchi, Y. Sakurai, and T. Okano, Anal. Chem., 1996, 68 , 105.

155.H. Kanazawa, T. Sunamoto, E. Ayano, Y. Matsushima, A. Kikuchi, and T. Okano, Anal. Sci., 2002, 18, 45.

156. Y. X. Song, J. Q. Wang, Z. X. Su, and D. Y. Chen, Chromatographia, 2001, 54, 208.

157. B. Buszewski, M. Jezierska-Świtala, and S. Kowalska, $J$. Chromatogr. B, 2003, 792, 279.

158. C. Baggiani, G. Giraudi, F. Trotta, C. Giovannoli, and A. Vanni, Talanta, 2000, 51, 71.

159.L. Ye, Y. Yu, and K. Mosbach, Analyst, 2001, 126, 760. 
160.E.-Y. Ting and M. D. Porter, Anal. Chem., 1997, 69, 675.

161.H. Deng, G. J. Van Berkel, H. Takano, D. Gazda, and M. D. Porter, Anal. Chem., 2000, 72, 2641.

162. J. L. Bernal, M. J. Del Nozal, G. A. Garcia Buj, and J. M. Juárez, J. Chromatogr., 1992, 607, 175.

163. K. Valkó, S. Espinosa, C. M. Du, E. Bosch, M. Rosés, C. Bevan, and M. H. Abraham, J. Chromatogr. A, 2001, 933, 73.

164. M. Z. Kagan, J. Chromatogr., 2001, 918, 293.

165.P. K. Zarzycki, K. M. Kulhanek, and R. Smith, J. Chromatogr. A, 2002, 955, 71.

166.P. K. Zarzycki and R. Smith, J. Chromatogr. A, 2001, 912, 45.

167. A. Pyka, J. Liq. Chromatogr. Relat. Technol., 2001, 24, 453.

168. E. Bonet-Domingo, M. J. Medina-Hernandez, and M. C. Garcia-Alvarez-Coque, J. Pharm. Biomed. Anal., 1993, 8, 711.

169.S. Torres-Cartas, R. M. Villanueva-Camañas, and M. C. Garcia-Alvarez-Coque, Chromatographia, 2000, 51, 577.

170. S. Torres-Cartas, J. R. Torres-Lapasio, R. M. VillanuevaCamañas, and M. C. Garcia-Alvarez-Coque, Chromatographia, 2000, 52, 185.

171.S. Torres-Cartas, R. M. Villanueva-Camañas, and M .C. Garcia-Alvarez-Coque, J. Liq. Chromatogr. Relat. Technol., 2000, 23, 1171.

172. M. J. Ruiz-Angel, R. D. Caballero, E. F. Simó-Alfonso, and M. C. Garcia-Alvarez-Coque, J. Chromatogr., 2002, 947, 31.

173. M.-E. Capella-Peiró, M. Gil-Augusti, L. Monferrer-Pons, and J. Esteve-Romero, Anal. Chim. Acta, 2002, 454, 125.

174.R. Gonzalo-Lumbreras and R. Izquierdo-Hornillos, J. Pharm. Biomed. Anal., 2003, 31, 201.

175. R. Gonzalo-Lumbreras and R. Izquierdo-Hornillos, J. Pharm. Biomed. Anal., 2003, 32, 433.

176. R. Gonzalo-Lumbreras and R. Izquierdo-Hornillos, $J$. Chromatogr., 2003, 794, 215.

177. N. S. Wilson, M. D. Nelson, J. W. Dolan, L. R. Snyder, R. G. Wolcott, and P. W. Carr, J. Chromatogr. A, 2002, 961, 171, 195.

178. V. Morris, J. Hughes, and P. Marriott, J. Chromatogr. A, 2003, 1008, 43.

179.D. Barron, J. A. Pascual, J. Segura, and J. Barbosa, Chromatographia, 1995, 41, 573.

180. Y. S. Gau, S. W. Sun, and R.-L. Chen, J. Liq. Chromatogr., 1995, 18, 2373.

181.I. Cenderowska and B. Buszewski, J. Liq. Chromatogr. Relat. Technol., 1999, 22, 2259.

182. V. Das Gupta and M. Mathew, Drug Dev. Ind. Pharm., $\mathbf{1 9 9 5}, 21,833$.

183. J. Zhu and C. Coscolluella, J. Chromatogr. B, 2000, 741, 55.

184. N. H. Anderson, M. R. Gray, and C. J. Hinds, J. Pharm. Biomed. Anal., 1990, 8, 853.

185. M. Mulholland, T. J. Whelan, H. Rose, and J. Keegan, J. Chromatogr. A, 2000, 870, 135.

186. W. J. Bachman and J. T. Stewart, J. Chromatogr. Sci., 1990, 28, 123.

187. A. M. Di Pietra, V. Andrisano, R. Gotti, and V. Cavrini, J. Pharm. Biomed. Anal., 1996, 14, 1191.

188. Alltech Application Note, 0046E, 2000, 2.

189. K. G. Flood, E. R. Reynolds, and N. H. Snow, J. Chromatogr. A, 2001, 913, 261.

190.E. H. Kerns, L. Di, S. Petusky, T. Kleintop, D. Huryn, O. McConnel, and G. Carter, J. Chromatogr. B, 2003, 791,
381.

191.X.-Y. Liu, C. Nakamura, Q. Yang, N. Kamo, and J. Miyake, J. Chromatogr. A, 2002, 961, 113.

192. Y. Zhao, J. Jona, D. T. Chow, H. Rong, D. Semin, X. Xia, R. Zanon, C. Spancake, and E. Maliski, Rapid Commun. Mass Spectrom., 2002, 16, 1548.

193.M. Molero-Monfort, L. Escuder-Gilabert, R. M. Villanueva-Camañas, S. Sagrado, and M. J. MedinaHernández, J. Chromatogr. B, 2001, 753, 225.

194. J. Li, J. Chromatogr. A, 2001, 927, 19.

195. J. Li and D. S. Shah, J. Chromatogr. A, 2002, 954, 159.

196. J. M. Lemus Gallego and J. Pérez Arroyo, Anal. Lett., 2002, 35, 2105.

197.S. Görög, M. Gazdag, and P. Kemenes-Bakos, J. Pharm. Biomed. Anal., 1996, 14, 1115.

198.P. Britz-McKibbin, T. Ichihashi, K. Tsubota, D. D. Y. Chen, and S. Terabe, J. Chromatogr. A, 2003, 1013, 65.

199.H. Nishi, T. Fukuyama, M. Matsuo, and S. Terabe, J. Chromatogr., 1990, 513, 279.

200.S. Terabe, Y. Ishihama, H. Nishi, T. Fukuyama, and K. Otsuka, J. Chromatogr., 1991, 545, 359.

201. J. Vindevogel and P. Sandra, Anal. Chem., 1991, 63, 1530.

202. M. Lin and N. Wu, J. Pharm. Biomed. Anal., 1999, 19, 945.

203. J. J. Berzas, B. Del Castillo, G. Castañeda, and M. J. Pinilla, Talanta, 1999, 50, 261.

204. J. J. Berzas, J. Rodríguez, G. Castañeda, and M. J. Pinilla, Chromatographia, 1999, 49, 65.

205. J. M. Lemus Gallego and J. Pérez Arroyo, J. Liq. Chromatogr. Relat. Technol., 2003, 26, 1011.

206.J. M. Lemus Gallego and J. Pérez Arroyo, Chromatographia, 2003, 58, 277.

207.J. M. Lemus Gallego and J. Pérez Arroyo, J. Pharm. Biomed. Anal., 2003, 31, 873.

208.J. M. Lemus Gallego and J. Pérez Arroyo, Fresenius' J. Anal. Chem., 2001, 370, 973.

209. S. E. Lucangioli, V. G. Rodríguez, G. C. Fernandez Otero, N. M. Vizioli, and C. N. Carducci, J. Capillary Electrophor., 1997, 4, 27.

210. S. Noé, J. Böhler, E. Keller, and A. W. Frahm, J. Pharm. Biomed. Anal., 1998, 18, 911.

211. A. Cifuentes, J. L. Bernal, and J. C. Diez-Masa, J. Chromatogr. A, 1998, 824, 99.

212.H. Okamoto, A. Uetake, R. Tamaya, T. Nakajima, K. Sagara, and Y. Ito, J. Chromatogr. A, 2001, 929, 133.

213.M. R. N. Monton, K. Otsuka, and S. Terabe, J. Chromatogr. A, 2003, 985, 435.

214.L. Vomastová, I. Mikšik, and Z. Deyl, J. Chromatogr. B, 1996, 681, 107.

215. S. Pedersen-Bjergaard, C. Gabel-Jensen, and S. H. Hansen, J. Chromatogr. A, 2000, 897, 375.

216. S. H. Hansen, C. Gabel-Jensen, and S. Pedersen-Bjergaard, J. Sep. Sci., 2001, 24, 643.

217.C. Gabel-Jensen, S. H. Hansen, and S. Pedersen-Bjergaard, Electrophoresis, 2001, 22, 1330.

218. S. E. Lucangioli, C. N. Carducci, S. L. Scioscia, A. Carlucci, C. Bregni, and E. Kenndler, Electrophoresis, 2003, 24, 984.

219. S. K. Poole, D. Durham, and C. Kibbey, J. Chromatogr., 2000, 745, 117; 2003, 793, 265.

220. R. B. Taylor, S. Vorarat, R. G. Reid, S. P. Boyle, and R. R. Moody, J. Capillary Electrophor., 1999, 6, 131.

221.J. Saevels, M. Wuyts, A. Van Schepdael, E. Roets, and J. Hoogmartens, J. Pharm. Biomed. Anal., 1999, 20, 513.

222. N. M. Djordjevic, F. Fitzpatrick, F. Houdiere, G. Lerch, and G. Rozing, J. Chromatogr., 2000, 887, 245. 
223. Y. Liu and D. J. Pietrzyk, J. Chromatogr. A, 2001, 920, 367.

224.J. Wang, D. E. Schaufelberger, and N. A. Guzman, J. Chromatogr. Sci., 1998, 36, 155.

225. M. R. Euerby, D. Gilligan, C. M. Johnson, S. C. P. Roulin, P. Myers, and K. D. Bartle, J. Microcol. Sep., 1997, 9, 373.

226. N. W. Smith and M. B. Evans, Chromatographia, 1994, 38, 649; 1995, 41, 197.

227.S. J. Lane, in "Identification and Determination of Impurities in Drugs", ed. S. Görög, 2000, Elsevier, Amsterdam, 359 - 381.

228.S. J. Lane, R. Boughtflower, C. Paterson, and T. Underwood, Rapid Commun. Mass Spectrom., 1995, 9, 1283.

229. R. N. Warriner, A. S. Craze, D. E. Games, and S. J. Lane, Rapid Commun. Mass Spectrom., 1998, 12, 1143.

230.P. M. Bersier and J. Bersier, in "Steroid Analysis in the Pharmaceutical Industry”, ed. S. Görög, Ellis Horwood, Chichester, $166-180$.

231.F. Belal, Microchim. Acta, 1992, 107, 11.

232.M. I. Walash, F. Belal, M. E.-S. Metwally, and M. Hefnawy, Microchim. Acta, 1994, 112, 217.

233. C. Jesaseelan and A. P. Joshi, Anal. Bioanal. Chem., 2002, 373,772 .

234. J.-E. Belgaied, Anal. Bioanal. Chem., 2003, 376, 706.

235.J. J. Berzas, J. Rodríguez, and G. Castañeda, Electroanalysis, 1999, 11, 268.

236. R. Aubeck, C. Bräuchle, and N. Hampp, Anal. Chim. Acta, 1990, 238, 405.

237.S. Görög, "Identification and Determination of Impurities in Drugs", 2000, Elsevier, Amsterdam, 712 - 731.

238. S. Görög, Anal. Bioanal. Chem., 2003, 377, 852.

239.S. Görög, M. Babják, G. Balogh, J. Brlik, F. Dravecz, M. Gazdag, P. Horváth, A. Laukó, and K. Varga, J. Pharm. Biomed. Anal., 1998, 18, 511.

240. S. Görög, G. Balogh, A. Csehi, É. Csizér, M. Gazdag, Zs. Halmos, B. Hegedüs, B. Herényi, P. Horváth, and A. Laukó, J. Pharm. Biomed. Anal., 1993, 11, 1219.

241.S. Görög, M. Babják, G. Balogh, J. Brlik, A, Csehi, F. Dravecz, M. Gazdag, P. Horváth, A. Laukó, and K. Varga, Talanta, 1997, 44, 1517.

242. M. Gazdag, M. Babják, J. Brlik, S. Mahó, Z. Tuba, and S. Görög, J. Pharm. Biomed. Anal., 1998, 17, 1029.

243. S. Görög, Trends Anal. Chem., 2003, 22, 407.

244. G. Cavina, R. Alimenti, B. Gallinella, and L. Valvo, J. Pharm. Biomed. Anal., 1992, 9, 685.

245. M. Spangler and E. Mularz, Chromatographia, 2001, 54, 329.

246.R. E. Conrow, G. W. Dillow, L. Bian, L. Xue, O. Papadopoulou, J. K. Baker, and B. S. Scott, J. Org. Chem., 2002, 6835.

247. N. Mistry, I. M. Ismail, M. G. Smith, J. K. Nicholson, and J. C. Lindon, J. Pharm. Biomed. Anal., 1997, 16, 697.

248. M. Ogata, Y. Noro, M. Yamada, T. Tahara, and T. Nishimura, J. Pharm. Sci., 1998, 87, 91.
249.P. Horváth, G. Balogh, J. Brlik, A, Csehi, F. Dravecz, Zs. Halmos, A. Laukó, M. Rényei, K. Varga, and S. Görög, J. Pharm. Biomed. Anal., 1997, 15, 1343.

250. S. Görög, M. Bihari, É. Csizér, F. Dravecz, M. Gazdag, and B. Herényi, J. Pharm. Biomed. Anal., 1995, 14, 85.

251.S. Görög, G. Balogh, and M. Gazdag, J. Pharm. Biomed. Anal., 1991, 9, 829.

252.S. Görög, Zs. Halmos, B. Herényi, A. Georgakis, G. Balogh, É. Csizér, and Z. Tuba, in "Advances in Steroid Analysis '90", ed. S. Görög, 1991, Akadémiai Kiadó, Budapest, 323 - 329.

253. S. Görög, J. Brlik, A, Csehi, Zs. Halmos, B. Herényi, P. Horváth, F. Dravecz, and D. Bor, Anal. Meth. Instrum., 1995, 2, 154 .

254.B. E. Segmuller, B. L. Armstrong, R. Dunphy, and A. R. Oyer, J. Pharm. Biomed. Anal., 2000, 23, 927.

255.G. Balogh, É. Csizér, Gy. G. Ferenczy, Zs. Halmos, B. Herényi, P. Horváth, A. Laukó, and S. Görög, Pharm. Res., 1995, 12, 295.

256. M. R. Euerby, J. A. Graham, C. M. Johnson, R. J. Lewis, and D. B. Wallace, J. Pharm. Biomed. Anal., 1996, 15, 299

257.M. Gazdag, M. Babják, P. Kemenes-Bakos, and S. Görög, J. Chromatogr., 1991, 550, 639.

258. M. Gazdag, G. Szepesi, and K. Mihályfi, J. Chromatogr., 1988, $450,145$.

259.H. Lamparczyk, P. K. Zarzycki, and J. Nowakowska, J. Chromatogr. A, 1994, 668, 413.

260. Y. Blom, M. Ek, J. T. Martin, and N. E. Stjernström, Pharmeuropa, 1993, 5, 381.

261. Gy. Szász, K. Gyimesi-Forrás, and Zs. Budvári-Bárány, J. Liq. Chromatogr. Relat. Technol., 1998, 21, 2535.

262.B. Chankvetadze, I. Kartozia, C. Yamamoto, and Y. Okamoto, J. Pharm. Biomed. Anal., 2002, 27, 467.

263. M. Kummer, H.-J. Palme, and G. Werner, J. Chromatogr. $A, \mathbf{1 9 9 6}, 749,61$.

264. M. Kummer and G. Werner, J. Chromatogr. A, 1998, 825 , 107.

265. A. Berthod, H. L. Jin, T. E. Beesly, J. D. Duncan, and D. W. Armstrong, J. Pharm. Biomed. Anal., 1990, 8, 123.

266. Macherey-Nagel Application Note, A-1103, 2001, 2.

267.D. Lubda, K. Cabrera, K. Nakanishi, and W. Lindner, Anal. Bioanal. Chem., 2003, 377, 892.

268. M. Jung and V. Schurig, J. High Res. Chrom., 1993, 16, 215.

269. Y. Liu, A. Berthod, C. R. Mitchell, T. L. Xiao, B. Zhang, and D. W. Armstrong, J. Chromatogr. A, 2002, 978, 185.

270. B. Chankvetadze, I. Kartozia, J. Breitkreutz, Y. Okamoto, and G. Blaschke, Electrophoresis, 2001, 22, 3327.

271.L. Chakvetadze, I. Kartozia, C. Yamamoto, B. Chankvetadze, G. Blaschke, and Y. Okamoto, J. Sep. Sci., 2002, 25, 653 .

272. G. Tárkányi, J. Chromatogr. A, 2002, 961, 257.

273.G. Tárkányi, in "Identification and Determination of Impurities in Drugs", ed. S. Görög, 2000, Elsevier, Amsterdam, 562 - 574. 